\title{
Sınıf Öğretmenlerinin Dijital Okuryazarlık Düzeylerinin İncelenmesi
}

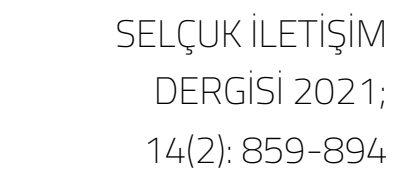

doi: $10.18094 /$ JOSC.871290

\section{Nuri Can Aksoy, Ersoy Karabay, Evrim Aksoy}

\section{Öz}

Dünyada olduğu gibi ülkemizde de hız kesmeden gelişen teknoloji çalışmaları eğitimde de kendini göstermektedir. COViD19 pandemi nedeniyle eğitimin ulusal çapta zorunlu olarak uzaktan yapılmasıyla eğitimde teknoloji kullanımı zorunlu hale gelmiştir. Bu süreç dijital yerli olarak adlandırılan günümüz öğrencilerine sürece uyum sağlamasının kendini geliştiren ve teknolojiyi derslerde kullanabilen öğretmenler ile mümkün olduğunu göstermiştir. Bu durumda öğretmenlerin dijital okuryazarlık becerileri uzaktan eğitimin verimliliği açısından önemlidir. Bu çalışmada, sınıf öğretmenlerinin dijital okuryazarlık becerilerinin çeşitli değişkenlere bağlı olarak incelenmesi amaçlanmıştır. Bu çalışma nicel araştırma yöntemlerinden tarama modeli kullanılarak gerçekleştirilmiştir. Çalışmaya Türkiye'nin yedi bölgesinden toplamda 41 ilde görev yapan 329 sınıf öğretmeni gönüllü olarak katılmıştır. Çalışmada veri toplama aracı olarak "Kişisel Bilgi Formu" ve "Dijital Okuryazarlık Ölçeği" kullanılmıştır. Araştırmadan elde edilen bulgulara göre araştırmanın birinci alt problemine ilişkin bulgularda sınıf öğretmenlerinin kendilerini yüksek düzeyde dijital okuryazar gördükleri sonucuna ulaşılmıştır. Cinsiyet değişkenine göre dijital okuryazarlık düzeylerine bakıldığında kadın ve erkek öğretmenlerin benzer düzeyde dijital okuryazar oldukları sonucuna ulaşılmıştır. Sınıf öğretmenlerinde yaş arttıkça dijital okuryazarlık düzeyinin azaldığı görülmüştür. Ayrıca lisansüstü eğitime sahip öğretmenlerin dijital okuryazarlık düzeyleri diğer öğrenim düzeyindeki öğretmenlere kıyasla daha yüksek bulunurken, 21-25 yıl kıdeme sahip öğretmenlerin dijital okuryazarlık düzeyleri diğer kıdemdeki öğretmenlere göre daha düşük bulunmuştur. Öğretmenlerin günlük internet kullanım ve günlük dijital araçları kullanım sürelerine bakıldığında anlamlı bir farklılaşma görülmemiştir.

Anahtar Sözcükler: Dijital Okuryazarlık, Bilgi Illetişim Teknolojileri, Sınıf Öğretmenleri, Eğitim, Iletişim

$\begin{array}{lll}\text { NURI CAN AKSOY } & \text { ERSOY KARABAY } & \text { EVRIM AKSOY } \\ \text { Dr. Öğr. Üyesi } & \text { Dr. Öğr. Üyesi } & \text { Öğretmen } \\ \text { Hasan Kalyoncu Üniversitesi } & \text { Ahi Evran Üniversitesi } & \text { Haydar Aliyev ilkokulu, MEB } \\ \text { ncan.aksoy@hku.edu.tr } & \text { e.karabay@ahievran.edu.tr } & \text { evrimaksoycan@gmail.com } \\ \text { ORCID ID: 000-0001-6087-8884 } & \text { ORCID ID: 000-0002-9499-2009 } & \text { ORCID ID: 0000-0002-9641-2143 }\end{array}$

SELÇUK ILETIŞIM DERGISI 2021; 14(2): 859-894

doi: 10.18094/ JOSC.871290

Geliş Tarihi: 30.01.2021 Kabul Tarihi: 23.03.2021 Yayın Tarihi: 25.04.2021 


\title{
The Investigation of the Digital Literacy Levels of Classroom
}

Teachers

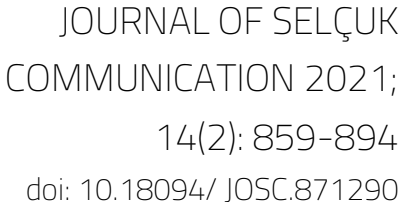

doi: $10.18094 /$ JOSC.871290

\section{Nuri Can Aksoy, Ersoy Karabay, Evrim Aksoy}

\begin{abstract}
Technology studies that develop in our country without slowing down, as in the world, also show itself in education. Due to the COVID-19 pandemic, the use of technology in education has become mandatory with the compulsory distance education at national level. This process has shown us that today's students, who are called digital natives, can adapt to the process with teachers who develop themselves and can use technology in lessons. In this case, digital literacy skills of teachers are important for the efficiency of education. In this study, it is aimed to examine the digital literacy skills of classroom teachers depending on various variables. This study was created using the survey model, one of the quantitative research methods. The study of Turkey's 41 provinces who served a total of 329 classroom teachers from seven regions participated voluntarily. "Personal Information Form" and "Digital Literacy Scale" were used as data collection tools. According to the findings obtained from the study, it was concluded that classroom teachers perceived themselves as digitally literate in the findings related to the first sub-problem of the study. Considering the digital literacy levels of the gender variable, it was concluded that male and female teachers were digitally literate at a similar level. It has been observed that as the age of the classroom teachers increases, the level of digital literacy decreases. In addition, digital literacy levels of teachers with postgraduate education were found to be higher than teachers of other education levels, while the digital literacy levels of teachers with a seniority of 21-25 years were found to be lower than those of other senior teachers. When we look at teachers' daily internet usage and daily digital tools usage, no significant differentiation was observed.
\end{abstract}

Keywords: Digital Literacy, Information Communication Technologies, Classroom Teachers, Education, Communication

NURI CAN AKSOY

Asst. Prof.

Hasan Kalyoncu University

ncan.aksoy@hku.edu.tr

ORCID ID: 000-0001-6087-8884

\author{
ERSOY KARABAY \\ Asst. Prof. \\ Ahi Evran University \\ e.karabay@ahievran.edu.tr \\ ORCID ID: 000-0002-9499-2009
}

\author{
EVRIM AKSOY \\ Öğretmen \\ Haydar Aliyev Primaryschool MEB \\ evrimaksoycan@gmail.com \\ ORCID ID: 0000-0002-9641-2143
}

JOURNAL OF SELÇUK COMMUNICATION 2021; 14(2): 859-894

doi: 10.18094/ JOSC.871290 


\section{Gíriş}

Günümüzde ihtiyaç duyulan her türlü bilgiye ulaşabilmek için yaşanan değişimleri dikkatle takip etmeli, yenilikleri yakından izlemeli ve teknolojik imkânlardan yararlanmak için yeterli seviyede bilgi sahibi olunması zaruri bir durumdur (Ahmet \& Yıldız, 2019). Eğitim politikalarında yapılan yenilikler çağa uymalı, çağın gerektirdiği teknolojik gelişimlerden nasibini almalı yeni bilimsel teknolojik gelişimler eğitim sisteminin parçası olmalıdır. Dünyada olduğu gibi Türkiye'de de bilimsel ve teknolojik gelişmelerin eğitim sisteminde kendine yer bulabilmesi, öğrencilerin bu gelişmelerden doğru şekilde faydalanabilmesi, eğitim öğretimin verimli şekilde etkilenmesi; kendini sürekli geliştiren, gelişim ve değişimleri yakından takip edip uygulayabilen, yenilikçi öğretmenlerle mümkün olacaktır. Toplumların kalkınıp gelişmesi için ihtiyaç duyulan nitelikli insan gücü ancak ve ancak iyi yetiştirilmiş öğretmenlerin verdikleri eğitim sayesinde mümkündür olabilir (Seferoğlu, 2001).

Toplumun ihtiyaç duyduğu nitelikli öğrencilerin yetişmesi için öncelikle öğretmenlerin bu niteliklere sahip olması beklenir. Şahin, yeterlik kavramını bir göreve ait sorumlulukları yerine getirebilmek için bilgi, beceri ve yeteneğe ihtiyaç duyulması olarak tanımlamıştır (2004). Öğretmenlik mesleğinde sözü geçen yeterlik ise öğretmenlerin hizmet alanı ile ilgili bilgi ve becerileri kazanması olarak ifade edilebilir.

Milli Eğitim Bakanlığı'nın öğretmen mesleğindeki yeterliklere yönelik yaptığı güncelleme çalışmaları neticesinde öğretmenlik mesleğinin yeterlikleri mesleki bilgi, beceri, tutum ve değerler olarak üç alan tanımlanmıştır (Milli Eğitim Bakanlığı, 2020). Mesleki Beceri başlıklı yeterlik alanında "Öğretme ve Öğrenme Sürecini Yönetme" yeterliği kapsamında bilgi iletişim teknolojilerinin etkili kullanılması göstergesinde belirtildiği üzere öğretmenlerin teknoloji kullanımlarıyla doğrudan ilişkilidir. Ayrıca öğretmenlerin teknoloji kullanımlarıyla Mesleki Bilgi başlığında, "Alan Eğitimi Bilgisi" kapsamında ve diğer bir yeterlik olan Tutum ve Değerler başlı̆ı altında, Kişisel ve Mesleki Gelişim kapsamında yer alan göstergeler ile de doğrudan ilişkili olduğu söylenebilir. Bu üç yeterlik alanı başlığı altında yer alan diğer yeterliklerle dolaylı olarak da teknoloji kullanımları ilişkilendirilebilir.

Öğretmenlik mesleğinin genel yeterlikleri, hizmet içinde bulunan öğretmenlerin kendilerine yönelik olumlu ve olumsuz yönlerini görmelerini sağlayacaktır (Metin Taş, 2019) . Öğretmen kalitesinin sağlanmasında önemli noktalar, hizmet öncesi öğretmen eğitimi ve hizmet içinde çalışan öğretmenlerin 
seçimi için kullanılan kriterlere dikkat edilmesi ve kariyeri süresince öğretmenlerle sürekli değerlendirme yapılmasıdır (OECD, 2021).

Öğretmenlik mesleği genel yeterlik alanlarıyla ilişkilendirilen teknoloji kullanımının, Covid-19 pandemi dönemi sürecinde eğitimin dijital araçlar üzerinden gerçekleştirilmesiyle birlikte önemi daha çok hissedilmektedir. COVID-19 salgını nedeniyle 2020 Mart ayında dünyada pandemi ilan edilmiştir. Hayatın her alanında etkisini gösteren Covid-19 eğitim öğretime yönelik uygulamaların yeniden değerlendirmesini gerekli kılan sonuçlar doğurmuştur. Ülkemizde pandemi sürecinde toplum sağlığı için alınan çeşitli önlemlerden biri ise yüz yüze eğitime ara vermek olmuştur. Pandemi sebebi ile kesintiye uğrayan eğitimi telafi etmek için tüm dünyada eğitim kurumları tarafından acil uzaktan eğitim uygulamaları başlamıştır (Bozkurt, 2020). Uzaktan eğitimin yaşam boyu öğrenme sürecinde kullanılabilen bir seçenek olduğu, acil uzaktan eğitimin ise kriz zamanlarında bir zorunluluk olduğu bilinmektedir (Bozkurt, ve diğerleri, 2020) .

Uzaktan eğitim için Türkiye'nin ulusal dijital eğitim platformu olan EBA ve televizyonlarda oluşturulan EBA TV kanalları ile uzaktan eğitim başlamıştır. EBA TV ve EBA uygulamalarının eğitim ortamında kullanıcıları başta öğrenciler, öğretmenler ve velilerdir. Uzaktan eğitimin verimli kullanımı için gerekli olan telefon bilgisayar tablet ve televizyon gibi dijital araçları kullanım becerisi gereklidir. Soby, dijital yetkinliğe sahip bilgi toplumunun interaktif katılımcıları olan yeni nesil için öğrenme ortamlarının geleneksel araç kullanımından uzaklaşarak daha fazla içerik ve motive eden dijital medya kullanımının artacağını belirtmiştir (Soby, 2008). Bu durum dijitalleşen sınıf ortamlarında öğrenci ve öğretmenlerin yeni araçların kullanıma yatkın olmasını gerekli kılabilir. Yeni nesil bireylerin dijital yaşamda kaliteli zaman geçirmeleri için iyi birer dijital okuryazar olmaları gerekmektedir (Özerbaş \& Kuralbayeva, 2018). Gelecek nesillerin dijital araçlar ile bilgive ulaşma yolunda uzmanlaşabilmesi için öncelikle öğrencilerin öğrenmesinde en önemli faktör olan öğretmenlerin dijital okuryazarlık becerisine sahip olmaları gerekmektedir (Metin Taş, 2019). Dijital okuryazarlık aslında bilgisayar tablet ve akıllı telefon gibi cihazları kullanarak doğru bilgiye ulaşmak, bilgiyi kullanabilmek, bilgiyi paylaşıp aktarabilmek ve bilgi üretmek anlamına gelmektedir.

Yaşanan gelişmeler sonucunda öğrencilerde kazandırılması amaçlanan bilgi, beceri ve tutumlar değiştikçe bu süreci planlayıp uygulayan öğretmenlerin de yeterlikleri değişmektedir (Boyacı, 2019) 
Teknolojiye olan ihtiyaç teknolojik araçların gelişmesine ya da teknolojik gelişmeler, yeni teknolojilerin eğitimde kullanılmasına olanak sağlarken, öğretmenlerin bu teknolojileri takip etmeleri ve kullanabilme becerileri gerekmektedir. Milli Eğitimin amaçlarının yer aldığı Milli Eğitim Temel Kanununda ders araç gereçleri ve ders programlarının bilimsel, teknolojik yenilikler ve ihtiyaçlar doğrultusunda sürekli gelişip değiştiği belirtilmiştir (Milli Eğitim Bakanlığı, 1973). Bu amaca paralel olarak öğretmenlerin amaçlarından biri de sürekli gelişen yöntem, araç ve gereçleri takip etme ve bu yöntem araç ve gereci kullanabilme becerisini geliştirmektir. Teknolojik araç ve gereçleri takip etme ve kullanma becerisine dijital okuryazarlık denir. Çağın gerektirdiği teknolojik gelişmeler sonucunda yeni bir beceri alanı olan dijital okuryazarlık ortaya çıkmıştır (Özbay \& Özdemir, 2014). Alanyazında dijital okuryazarlığının, bilgi okuryazarlığı, bilgi iletişim teknolojileri (BiT), medya okuryazarlı̆̆ı, 21. yüzyıl becerileri ile ilişkili olduğuna dair ifadeler yer almaktadır (Alexander, ve diğerleri, 2012; List, Brante, \& Klee, 2020; Spante, Hashemi, Lundin, \& Algers, 2018). Tanımlardan yola çıkarak, dijital okuryazarlık teknik, bilişsel ve sosyo-duygusal olmak üzere üç boyuta ayrılabilir. Teknik ve operasyonel beceriler, teknik boyutu, arama, değerlendirme ve eleştirel düşünme gibi beceriler bilişsel boyutu oluştururken, sosyal-duygusal boyutu iletişim, iş birliği ve öğrenmeye yönelik hedeflerde sorumluluk için BiT kullanılmasıdır (Ng, 2012). Dijital okuryazarlık, bilgi, medya ve bilgi teknolojileri okuryazarlığını kapsamaktadır (Yıldııı \& Kurşun, 2020).

Okuryazar bireyler edindiği bilgiyi toplumsal ve sosyal çevresinde doğru bir şekilde kullanabilmektedir (Kane, 2017). Özellikle günümüzde Z kuşağı dijital yerliler (Prensky, 2001) olarak adlandırılan öğrenciler ve uzaktan eğitim ortamları düşünüldüğünde, öğretmenlerden teknolojik araçlarla eğitim ortamlarını zenginleştirmeleri ve dijital okuryazarlık becerilerinin yüksek olması beklenir (Boyacı, 2019). Bu amacın gerçekleşebilmesi için öğretmenlerin teknoloji alanında güncel becerilerden dijital okuryazarlık becerisine sahip olması gerekir.

\section{Dijital Okuryazarlık}

Dijital okuryazarlık, bireylerin bilgi-iletişim teknolojilerini öğrenmede etkin olmasını, kişisel gelişimine teknolojiler ile katkı sağlamasını, günlük yaşam problemlerinin çözümünde kullanabilmesini ve teknoloji kullanımının güvenlik, yasal ve ahlaki olma boyutlarında yeterli olmasını kapsamaktadır (Özerbaş \& Kuralbayeva, 2018). 
Alan yazında dijital kaynaklara erişim ve bu kaynakları doğru şekilde kullanma yetkinliği olarak ifade dilmektedir (Karabacak \& Sezgin, 2019). Dijital okuryazarlık Gilster'e (1997) göre bilgivi bilgisayarın sunmuş olduğu değişik formatlarda değerlendirebilme bilgiyi anlama ve ön bilgilere entegre edebilme yeteneğidir (Akt. Yontar, 2019). Dijital okuryazarlı̆ın araştırmacılar tarafından farklı tanımları mevcuttur. Ribble dijital okuryazarlığı teknolojinin kullanımı ve teknolojiyle ilgili öğrenme öğretme süreçlerini kapsadığını belirtmiştir (2011, s. 26). Dijital okuryazarlığı Martin ise bireylerin dijital araçları kullanabilmeleri için dijital araçlara yönelik tutumlarını ve yeteneklerini geliştirmelerini; dijital kaynaklara erişim sağlayıp değerlendirmelerini, analiz sentez yaparak yeni bilgi oluşturmalarını ve kişilerin bu süreci sosyal hayatlarına yansıtabilmeleri olarak tanımlamıştır (2005). Dijital okuryazarlık becerisi bu tanımlar ışığında, dijital araçlar kullanılarak yeni bilgilere ulaşma, problemlerin çözümünde kullanma, bilgi ile işlem yapabilme, dijital teknolojileri etkili ve güvenli bir şekilde kullanma yeteneği şeklinde ifade edilebilir (Pala \& Başıüyük, 2020).

Dijital okuryazarlık, bilinçli ve bilgilendirmeci kullanım, bilme, silme, dijital güvenlik ve destek hakları ile birlikte çocuklar için bir hak olarak tanımlanmıştır (Karakuş Yılmaz, 2020). Dijital okuryazar becerisine sahip olma durumu bireylerin dijital sorumlulukları arasında yer almaktadır (BTK \& Yeşilay, 2014). Ayrıca dijital ebeveynlerin farkında olma, kontrol, etik ve yenilikçilikle birlikte beş temel becerisinden biri dijital okuryazarlıktır (Kabakçı Yurdakul, Dönmez, Yaman, \& Odabaşı, 2013). Her ebeveyn dijital okuryazarlık becerileri edinmeli, yeni teknolojileri takip etmeli, çocuğunun yaşayabileceği risklerin farkında olmalı, çocuğunu yönlendirebilmelidir (Karakuş Yılmaz, 2020) .

Öğretmenler, öğrencilerin özgün ürünler ortaya koymaları ve dijital içerik tasarlamaları sürecinde intiyaç duydukları desteği sağlamalıdır. Öğrencilerin çevresi ile iş birliği yapmaları sürecinde etkili iletişim kurup, kültürel ve sosyal anlayış geliştirmelerinde teknolojiyi nasıl ve ne zaman kullanacaklarını kavramalarına yardımcı olabilirler. Öğrencilerin sınıf ortamlarında dijital okuryazarlık becerilerini edinip geliştirebilmeleri için öğretmenlerin destek olmaları önemli görülmektedir (T.C. Milli Eğitim Bakanlığıı 2020). Öğretmenler, birey ve ebeveyn olarak dijital okuryazar olma sorumlulukları taşımaktadır. Bu sorumluluklarla birlikte özellikle dijital okuryazarlığın çocuklar için bir hak olarak tanımlanması, öğrencilerin bu hakka erişebilmeleri ve bu hakkı kullanabilmeleri için öğretmenlerin rol model olmaları adına yüksek düzeyde dijital okuryazarlık becerisine sahip olması gereklidir. Gelecek nesillerin dijital 
araçlar ile bilgiye ulaşmada uzmanlaşabilmesi için öncelikle öğretmenlerde bu becerilerin var olması beklenir.

Öğretmen adayları ile yürütülen araştırmalarda, cinsiyet ve sınıf düzeyi değişkenlerinin incelendiği alanyazında görülmektedir. Kadın öğretmen adaylarının, erkeklere kıyasla daha iyi dijital okuryazar olduğu (Boyacı, 2019; Alhazza \& Lucking, 2017), sonucuyla birlikte, dijital okuryazarlık düzeyleri erkek öğretmen adaylarının kadınlara göre daha iyi olduğu yönelik araştırma sonuçları da mevcut (Özerbaş \& Kuralbayeva, 2018; Yontar, 2019; Ata \& Yıldırım, 2019; Zhou, 2014) olsa da cinsiyet değişkenin dijital okuryazarlık düzeyi üzerinde etkili olmadı̆̆ında dair araştırmalar bulunmaktadır (Maden, Banaz, \& Maden, 2018; Aslan \& Zhu, 2017; Tondeur, Aesaert, Prestridge, \& Consuegra, 2018).

Öğretmen adayları üzerinde dijital okuryazarlık ölçeği kullanılarak yapılan incelemelerde yaş değişkeni incelenmemiş onun yerine sınıf düzeyleri arasındaki farklılık ele alınmıştır. Araştırmalarda sınıf düzeyi değişkeni incelendiğinde tutum, teknik ve bilişsel alt boyutlarında öğretmen adaylarının 2. 3. ve 4. sınıf düzeylerindeki öğrencilerin dijital okuryazarlık düzeylerinin kısmen anlamlı olduğu görülmüştür (Boyacı, 2019). Özçelik ve Yıldız'ın çalışmaları sonucunda öğretmenlerin mesleklerini icra ederken teknolojik gelişimi yakından takip etme konusunda yaş, cinsiyet ve mesleki kıdem değişkenlerinin rol oynadığı sonucuna ulaşmışlardır (2019). Buradan hareketle dijital okuryazarlık araştırmalarında cinsiyet yaş ve kıdemin önemli bir değişken olduğu söylenebilir. Akkoyunlu, 23 farklı ilköğretim okulunda görev yapan 7 farklı branşta ve en fazla 20 yıllık mesleki deneyime sahip 659 öğretmenin internet kullanımlarına ilişkin branş, yaş, mesleki deneyim, internet kullanım amacı ve öğretim sürecindeki kullanım düzeylerini incelediği çalışmasında; çalışmaya katılanların \%26'sının bilgisayar kullandığını ve öğretim sürecinde internet etkili olarak kullanmadığı sonucuna ulaşmışlardır (2002). Bu durumun sebebinin teknoloji ve dijital araçların kullanımının yaygın olmaması olduğu düşünülmektedir. Aradan geçen zaman, teknolojideki gelişimler ve ilerlemeler doğrultusunda benzer çalışmalar yinelenmiştir. Özbek (2020) öğretmenlerin dijital içerikleri ve teknoloji kullanım becerilerine ilişkin yapmış olduğu çalışmasında, Denizli illi Acıpayam İlçesinde görev yapmakta olan 304 öğretmenden tesadüfi örnekleme yöntemiyle belirlenen ve evreni temsil ettiği özellikleri taşıdığı belirtilen 128 öğretmenden "eğitim teknolojisi standartlarına yönelik öz yeterlik ölçeği" kullanılarak veriler toplanmıştır. Çalışma incelendiğinde; öğretmenlerin teknoloji ve dijital içerik kullanım becerilerinin iyi düzeyde olduğu ve öğretim süreçlerinde dijital araçları kullanabilme yeterliğinde oldukları sonucuna ulaşılmıştır (2020). 
Tatı'ının Gaziantep ili Nurdağı İlçesinde görev yapmakta olan öğretmenlerin tamamına ( $n=161$ ) ulaştıkları, dijital vatandaşık, bilgi okuryazarlığı ve bilgisayar ve internet kullanımı özyeterlilik algısı ölçeği olmak üzere üç farkı ölçeğin kullanıldığı çalışmasında, dijital vatandaşıık düzeylerinin cinsiyet ve internet kullanım amacına göre farkılış̧madığı, internet ve bilgisayar kullanım düzeylerinin artması ile bilgi okuryazarlık becerisinin arttığı sonucuna ulaşmıştır (2018).

Literatürden hareketle, dijital okuryazarlık araştırmalarında öğretmen adayları üzerinde geliştirilen dijital okuryazarlık ölçeğinin (Ng, 2012), öğretmen adayları ile yürütülen çalışmalarda kullanıldığı görülmüştür. Öğretmen adayları ile yürütülen dijital okuryazarlık düzeylerinin cinsiyet değişkenine ilişkin incelendiği sınırlı sayıda çalışma bulunmaktadır ve bu çalışmaların sonuçlarında farklııklar bulunmaktadır. Alanyazında farklı bölümlerde öğrenim gören öğretmen adaylarının bölümlerine göre dijital okuryazarlık düzeylerinin incelendiği araştırmalar da görülmüştür. Ancak öğretmenlerin dijital okuryazarlık düzeyleri üzerinde yapılmış araştırmaya rastlanılmamıştır. Bu çalışmanın görev yapmakta olan öğretmenlerin dijital okuryazarlık düzeylerinin incelenmesinde bir ilk olması bakımından bundan sonra öğretmenlerin dijital okuryazarlık düzeylerinin incelenmesine yönelik yürütülecek olan çalışmalara öncülük edeceği düşünülmektedir. Bu bakımdan araştırmanın öğretmenlerin dijital okuryazarlık düzeylerine ilişkin yapılacak olan çalışmalara kaynak oluşturması rolü ile katkı sağlayacaktır.

Bu çalışmada sınıf öğretmenlerinin dijital okuryazarlık becerilerinin farklı değişkenler açısından incelenmesi amaçlanmıştır. Bu amaca yönelik araştırmada cevabı aranan araştırma soruları aşağıda ifade edilmiştir:

1. Sınıf öğretmenlerinin dijital okuryazarlık ne düzeydedir?

2. Sınıf öğretmenlerinin dijital okuryazarlık düzeylerinin

- Cinsiyet

- Yaş

- Öğrenim düzeyine

- Kıdem yılına

- İnternet kullanım süresi

- Dijital araç kullanım süresi 
göre anlamlı farklılık göstermekte midir?

\section{YÖNTEM}

\section{Araştırma Modeli}

$\mathrm{Bu}$ araştırma, öğretmenlerin dijital okuryazarlık düzeylerinin incelendiği betimsel bir araştırmadır. Bu bağlamda nicel araştırma yöntemleri içerisinden tarama modeli tercih edilmiştir. Tarama modelinde belirlenen bir konuya ilişkin sorulan soruların ve cevapların betimlendiği bir yöntemdir (Jackson, 2015). Betimsel tarama, geniş gruplar üzerinde yürütülen, gruptaki bireylerin bir olgu ve olayla ilgili görüşlerinin, tutumlarının alındığı, olgu ve olayların betimlenmeye çalışıldığı araştırmalardır (Karakaya, 2012: 59). Bu modellemede genellemeye varılmak için veri toplama geniş çapta yapılmalıdır (Cohen, Manion, \& Morrison, 2017). Tarama modelinde evrenin içinden seçilmiş örneklemden veriler elde edilir ve evrenle ilgili çıkarımlar yapılıp elde edilen bulgular evrene genellenir. Tarama modelinde çalışmanın örnekleminden hareketle evrene yönelik tutum, eğilim ve görüşlere ilişkin nümerik veya nicel bir betimleme yapılması sağlanır (Akt. Pala \& Başıbüyük, 2020).

Bu çalışmada öğretmenlerin cinsiyet, yaş, öğrenim düzeyi, kıdem yılı; günlük internet kullanım ve dijital araçların kullanım sürelerine yönelik değişkenler ile dijital okuryazarlık becerisi arasındaki ilişkinin var olup olmadığı incelendiği için tarama yöntemi kullanıımıştır.

\section{Çalışma Grubu}

Bu çalışmanın çalışma grubunu, 2020-2021 eğitim öğretim yılında Millî Eğitim Bakanlığı'na bağlı resmi devlet ilkokullarında görevini yapmakta olan 329 sınıf öğretmeni oluşturmuştur. Türkiye'nin yedi bölgesinden sınıf öğretmenleri gönüllü olarak çalışmaya katılmıştır. Ege Bölgesinde yer alan 5 il, Marmara Bölgesinde bulunan 4 il, Karadeniz Bölgesinden 7 il, Akdeniz Bölgesinden 6 il, iç Anadolu Bölgesinden 4 il, Doğu Anadolu Bölgesinden 10 il ve Güneydoğu Anadolu Bölgesinde yer alan 5 il olmak üzere toplamda 41 ilden öğretmenler çalışmaya dâhil olmuştur.

Çalışma grubuna ilişkin sınıf öğretmenlerinin cinsiyet, yaş, öğrenim düzeyi, kıdem yıll, görev yapıldığı il, günlük internet kullanım, dijital araçları (akıllı telefon, bilgisayar tablet, televizyon) kullanım sürelerine ve interneti kullanım amaçları ile ilgili dağılımları Tablo 1'de belirtilmiştir. 
Tablo 1 Sınıf Öğretmenlerinin Demografik Bilgilerine Göre Dağılımları

\begin{tabular}{|c|c|c|c|}
\hline DEMOGRAFIK ÖZELLIKLER & & $\mathrm{n}$ & $\%$ \\
\hline \multicolumn{4}{|l|}{ Cinsiyet } \\
\hline & Kadın & 186 & 56.5 \\
\hline & Erkek & 143 & 43.5 \\
\hline \multicolumn{4}{|l|}{ Yaş } \\
\hline & $20-25$ & 40 & 12.2 \\
\hline & $26-30$ & 91 & 27.7 \\
\hline & $31-35$ & 46 & 14.0 \\
\hline & $36-40$ & 64 & 19.5 \\
\hline & $41-45$ & 24 & 7.3 \\
\hline & $46-50$ & 27 & 8.2 \\
\hline & 51 ve üzeri & 37 & 11.2 \\
\hline \multicolumn{4}{|l|}{ Öğrenim düzeyi } \\
\hline & Ön lisans & 8 & 2.4 \\
\hline & Lisans & 281 & 85.4 \\
\hline & Yüksek lisans & 38 & 11.6 \\
\hline & Doktora & 2 & 6 \\
\hline \multicolumn{4}{|l|}{ Kıdem } \\
\hline & $0-5$ & 119 & 36.2 \\
\hline & $6-10$ & 45 & 13.7 \\
\hline & $11-15$ & 49 & 14.9 \\
\hline & $16-20$ & 44 & 13.4 \\
\hline & $21-25$ & 30 & 9.1 \\
\hline & 26 yıl ve üzeri & 42 & 12.8 \\
\hline \multicolumn{4}{|c|}{ Günlük internet kullanım süresi } \\
\hline & 1 saat & 11 & 3.3 \\
\hline & $2-3$ saat & 85 & 25.8 \\
\hline & 4-5 saat & 123 & 37.4 \\
\hline & 6 saat ve üzeri & 110 & 33.4 \\
\hline \multicolumn{4}{|c|}{ Günlük dijital araçları kullanma süresi } \\
\hline & 1 saat & 7 & 2.1 \\
\hline & $2-3$ saat & 81 & 24.6 \\
\hline & 4-5 saat & 112 & 34.0 \\
\hline & 6 saat ve üzeri & 129 & 39.2 \\
\hline
\end{tabular}

Tablo 1 de çalışma grubunu oluşturan Milli Eğitim Bakanlığı'na bağlı devlet okullarında görevini yapmakta olan 329 sınıf öğretmeninden 186'sı kadın (\%56.5), 143'ü erkek (\%43.5) öğretmendir. Sınıf öğretmenlerinin 40' ו (\%12.2) 20-25 yaş aralı̆̆ında, 91'i (27.7) 26-30 yaş aralığında, 46'sı (\%14.0) 31-35 
yaş aralığında, 64'ü (\%19.5) 36-40 yaş aralığında, 24'ü (\%7.3) 41-45 yaş aralığında, 27'si (\%8.2) 46-50 yaş aralığında, 37'si (\%11.2) 51 yaş ve üzeri yaştaki öğretmenlerden oluşmaktadır. Öğretmenlerin 8'i (\%2.4) ön lisans, 281'i (\%85.4) lisans, 38'i (\%11.6) yüksek lisans, 2'si (\%.6) doktora öğrenim düzeyine sahiptir. Sınıf öğretmenlerinin 119'u (\%36.2) 0-5 yıl, 45'i (\%13.7) 6-10 yıl, 49'u (\%14.9) 11-15 yıl, 44'ü (\%13.4) 1620 yıl, 30'u (\%9.1) 21-25 yıl, 42'si (\%12.8) 26 yıl ve üzeri kıdeme sahip öğretmenlerdir. Öğretmenlerin günlük internet kullanım süresi 0-1 saat olanlar 11 kişi (\%3.3), 2-3 saat 85 kişi (\%25.8), 4-5 saat 123 kişi (\%37.4), 6 saat ve üzeri 110 (\%33.4) kişidir. Dijital araç kullanım sürelerine bakıldığında 1 saatten az kullanan 7 kişi (\%2.1), 2-3 saat kullanan 81 kişi (\%24.6), 4-5 saat kullanan 112 kişi (\%34.0), 6 saat ve üzeri kullanan 129 (\%39.2) kişi olduğu ayrıca bu araştırmada yer alan katılımcıların, \%43.5'u erkek, \%56.5'u kadın öğretmenler olduğu görülmüştür.

\section{Veri Toplama Araçları}

Çalışmada veri toplama aracı olarak sınıf öğretmenlerinin kişisel bilgileri ile dijital okuryazarlık düzeylerini belirlemek için 'Kişisel Bilgi Formu' ve 'Dijital Okuryazarlık Ölçeği' kullanılmıştır. Veri toplama aracı iki bölümde toplanmıştır. İlk bölümde katılımcıların kişisel bilgileri diğer bölümde ise dijital okuryazarlık ölçeği kullanılmıştır.

Kişisel bilgi formu

Bu bölümde araştırmaya katılan sınıf öğretmenleri hakkında bilgi edinmek için 8 maddelik kişisel bilgi formu oluşturulmuştur. Formda katılımcıların cinsiyet, yaş, öğrenim düzeyi, kıdem yıll; görev yapıldığı il, günlük internet kullanım, dijital araçları (akıllı telefon, bilgisayar tablet, televizyon) kullanım sürelerine yönelik kişisel bilgilere yer verilmiştir.

Dijital Okuryazarlık Ölçeği

Dijital okuryazarlık ölçeği Ng tarafından Avustralya'daki bir üniversitede öğrenim gören öğretmen adaylarına uygulanarak geliştirilmiştir (2012). Ölçeğin Türkçe uyarlaması Hamutoğlu vd., (2017) tarafından yapılmıştır. 17 maddeden oluşan ölçek teknik, tutum, sosyal, bilişsel olarak adlandırılan dört faktöre sahiptir. Ölçekte beşli Likert tipi dereceleme kullanılmış olup (1) kesinlikle katılmıyorum, (5) kesinlikle katılıyorum şeklindedir. Ölçekte yer alan 1-7. Maddeler tutum, 8-13. maddeler teknik, 14. ve 15. maddeler bilişsel, 16. ve 17. maddeler sosyal boyutu ölçmektedir (Ng, 2012). 
185 öğrenciye uygulanan ölçeğin Cronbach Alfa Katsayısı .93 bulunmuştur. Alt boyutlara ait güvenirlik katsayıları teknik alt boyutu .89, tutum alt boyutu .88, bilişsel alt boyutu .70, sosyal alt boyutu .72 olarak bulunmuştur. Ölçeğin güvenirliğini sağlamak amacıyla test tekrar test yöntemi kullanılmıştır. "Test tekrar test yöntemi ile hesaplanan güvenirlik katsayıları ölçeğin tümü için .98, Tutum alt boyutu için .89, Teknik alt boyutu için .90, Bilişsel alt boyutu için .87 ve Sosyal alt boyutu için .79 şeklindedir" (Hamutoğlu, Güngören, Kaya Uyanık, \& Gür Erdoğan, 2017, s. 421). Ölçeklerin güvenirlik katsayısının .70 ve üzerinde olduğunda güvenilir olduğu kabul edilmektedir (Büyüköztürk, 2010).

\section{Verilerin Analizi}

Araştırma kapsamında verileri analiz etmede hangi yöntemlerin kullanılacağına karar vermek amacıyla öncelikle Kolmogorov-Smirnov normallik testi yapılıp, çarpıklık değerleri ve basıklık değerleri, histogram grafikleri incelenmiştir. Normallik testi sonucu Tablo 2'de belirtilmiştir.

Tablo 2 Dijital Okuryazarlık Ölçeği ve Alt Boyutlarına İlişkin Normallik Testi Sonuçları

\begin{tabular}{lrrrrr}
\hline & DOÖ & TUTUM & TEKNIK & BILIŞSEL & SOSYAL \\
\hline $\mathrm{n}$ & 329 & 329 & 329 & 329 & 329 \\
$\overline{\mathrm{X}}$ & 68.03 & 28.36 & 23.89 & 8.33 & 7.46 \\
$\mathrm{~S}$ & 8.22 & 3.75 & 3.35 & 1.11 & 1.55 \\
Median & 68 & 28 & 24 & 8 & 8 \\
Minimum & 48 & 17 & 14 & 5 & 4 \\
Maksimum & 85 & 35 & 30 & 10 & 10 \\
Kolmogorov-Smirnov & .06 & .09 & .15 & .26 & .17 \\
P & .005 & .000 & .000 & .000 & .000 \\
Çarpıklık & .14 & -.12 & .00 & -.22 & -.21 \\
Basıklık & -.28 & -.45 & -.01 & .12 & -.47 \\
\hline
\end{tabular}

Tablo 2'ye bakıldığında Kolmogorov-Smirnov testi sonuçlarına göre dijital okuryazarlık ölçeği ve alt boyutlarının normal dağılmadığı $(p<.05)$ görülmektedir. Sadece bu test sonucuna bakarak karar verilmeyip çarpıklık değerleri ve basıklık değerleri ile histogram grafikleri incelenmiştir. Verilerin normalden önemli bir sapma göstermediği, bu yüzden normal dağılıyor şeklinde yorumlanabileceği görülmüştür. Bu durumda verileri analiz etmede betimsel istatistikler, ilişkisiz örneklemler t testi ve ilişkisiz ölçümlerde tek yönlü varyans analizi (One WAy ANOVA) yapıImasına karar verilmiştir. Ayrıca yapı 
geçerliğini test etmek amacı ile doğrulayıcı faktör analizi yapılmış, güvenirlik için Cronbach'ın alpha katsayısı hesaplanmıştır. Verileri analiz etmede SPSS 25 ve LISREL 8.8 yazılımları kullanılmıştır.

Ölçeğe ait puanların düzeyini belirlemek amacıyla adım hesabı yapılmıştır. (Son kategori - İlk kategori) / Kategori sayısı formülü kullanılarak (5-1) / $5=0.8$ değeri bulunmuştur. Elde edilen puan madde sayısına bölündüğünde nasıl değerlendirileceği Tablo 3'te belirtilmiştir.

Tablo 3 Ölçekten Elde Edilen Puan Ortalamalarının Yorumlanması

\begin{tabular}{ll}
\hline ORTALAMA / MADDE SAYISI & KARAR \\
\hline $1.00-1.79$ & Çok düşük \\
$1.80-2.59$ & Düşük \\
$2.60-3.39$ & Orta \\
$3.40-4.19$ & Yüksek \\
$4.20-5.00$ & Çok yüksek \\
\hline
\end{tabular}

Tablo 3'e bakıldığında puan ortalamalarının madde sayısına bölünmesi ile elde edilen değer 1 ile 1.79 arasında ise dijital okuryazarlığın çok düşük, 4.20 ve üzerinde ise çok yüksek bulunacağı görülmektedir.

\section{Veri Toplama Araçları}

Araştırma kapsamında kullanılan Dijital Okuryazarlık Ölçeğinin yapı geçerliğini incelemek amacıyla Doğrulayıcı Faktör Analizi (DFA) yapılmıştır. DFA'nın varsayımları; örneklem büyüklüğü, kayıp değerler, normallik, doğrusallık, çoklu bağlantı ve tekillik ve uç değerler şeklinde sıralanabilir.

Öncelikle 339 katııımcıya ulaşılmıştır. Uç değer olan 10 veri, veri setinden çıkarılmış ve 329 kişiye ait veriyle analize devam edilmiştir.

Comrey \& Lee (1992) 329 katılımcı sayısını iyi olarak nitelendirmektedirler. Diğer bir ölçüt de KMO testi sonuçlarıdır. Araştırma kapsamında hesaplanan KMO sonuçları Tablo 4'te verilmiştir.

Tablo 4 Dijital Okuryazarlık Ölçeği Iç̧in Hesaplanan KMO Değerleri

\begin{tabular}{ll}
\hline KMO & $\mathrm{p}$ \\
\hline .909 & .000 \\
\hline
\end{tabular}


Leech, Barrett ve Morgan'a göre KMO değerinin .90 ve üzerinde olması örneklem büyüklügünün mükemmel olduğunu göstermektedir (2005). Normallik incelenmiştir. Normallik için ölçek maddelerinden toplam puan alınmış, Kolmogorov-Smirnov testi yapılmış, çarpıklık ve basıklık değerleri ile histogram grafikleri incelenmiştir. Kolmogorov-Smirnov testi sonuçlarına göre ölçek puanları normal dağılım göstermemektedir ( $\mathrm{p}<$.05). Ancak çarpıklık değerleri -1 ile +1 değerleri arasındadır (çarpıklık = .14, basıklık =-.28). Bu durumda ölçekten elde edilen puanların normal dağılımdan önemli bir sapma göstermediği, normal dağıldığı şeklinde yorumlanmıştır.

Tabachnick ve Fidell (2001) faktör sayısını saptamak ya da doğrulamak istendiğinde çok değişkenliğin olduğu sayıltısının kullanılmasını önermektedir. Bu araştırmada da bu sayıltı kullanılmıştır. Varsayımların test edilmesinden sonra DFA analizine geçilmiştir. Boş olan değerler ortalama değer atama yöntemiyle doldurulmuştur. Yapılan DFA sonucu t değerleri Şekil 1'de verilmiştir.

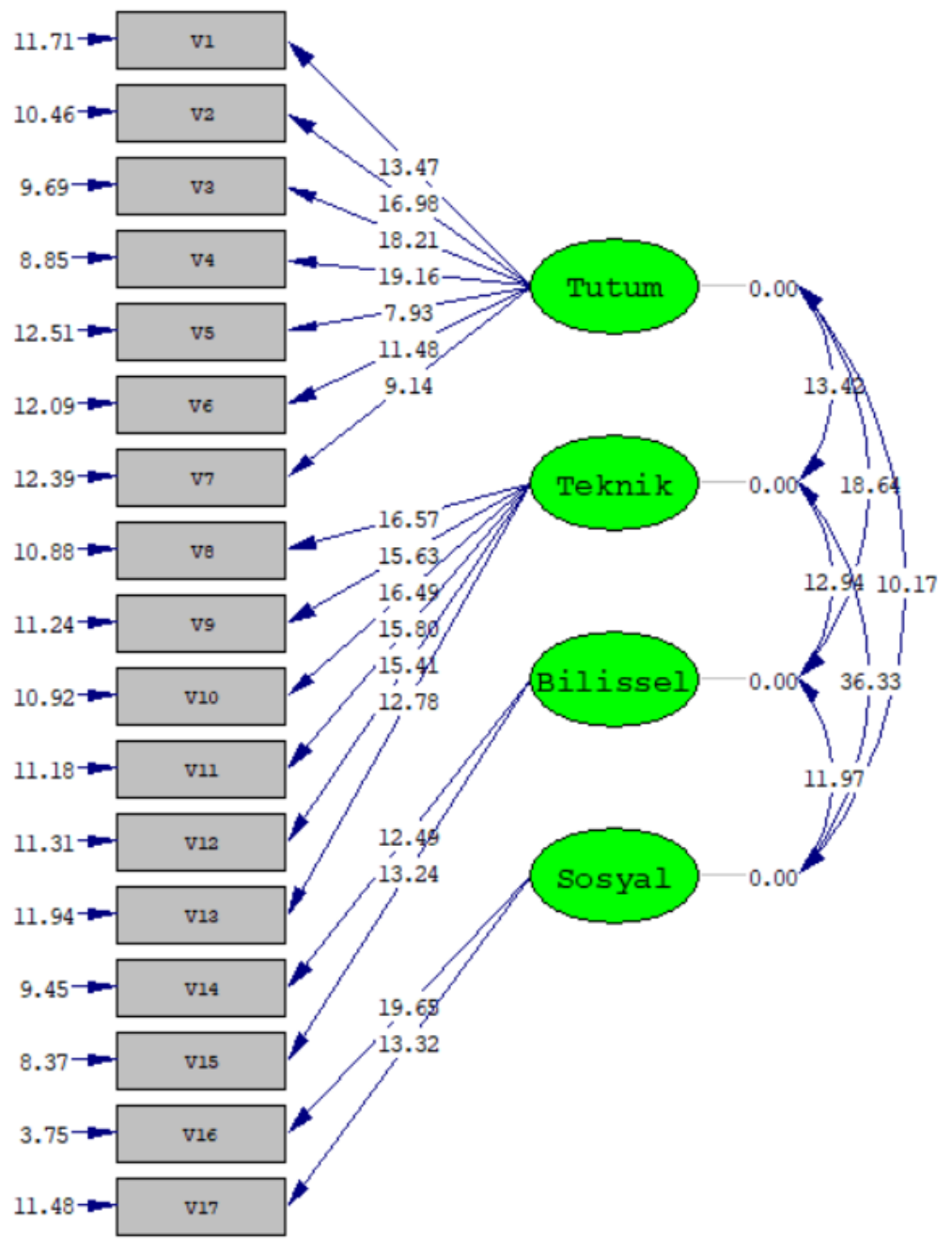

Chi-Square $=523.62, \mathrm{df}=113, \mathrm{P}$-value $=0.00000, \mathrm{RMSEA}=0.105$

Şekil 1 Dijital Okuryazarlık Ölçeği Birinci Düzey DFA t Değerleri 
DFA'da ilk olarak t değerleri incelenmiştir. T değerinin 1.96'yı aşması .05 düzeyinde, 2.56'yı aşması ise .01 düzeyinde anlamlı olduğunu göstermektedir. $T$ değerlerine göre tüm maddeler .01 düzeyinde anlamlıdır. Bu gizil değişkenlerin gözlenen değişkenleri doğru bir şekilde açıkladığını göstermektedir. Daha sonra standartlaştırılmış çözüm değerleri incelenmiştir. Bu değerler Şekil 2'de verilmiştir.

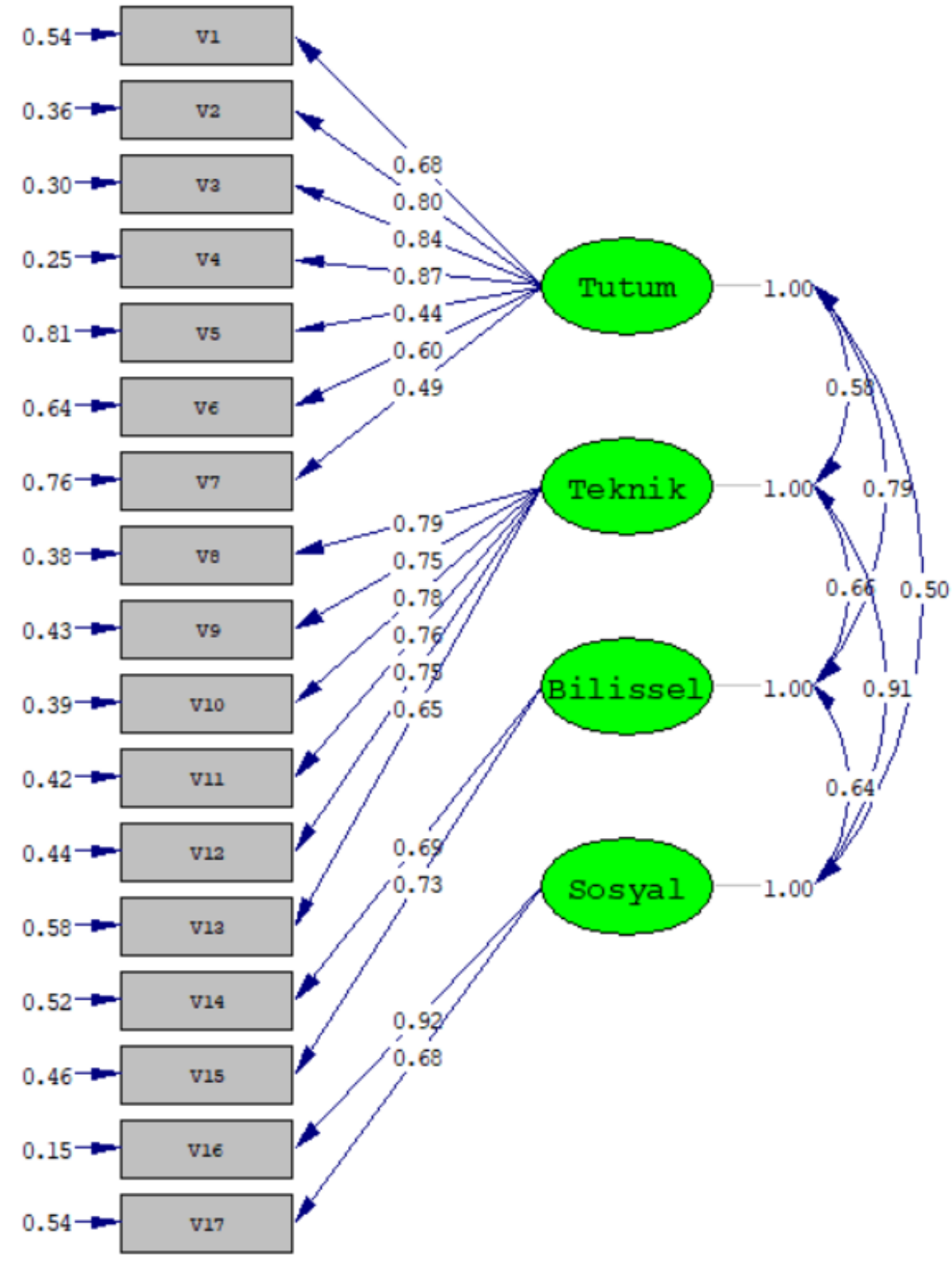

Chi-Square $=523.62$, df $=113, \mathrm{P}$-value $=0.00000, \mathrm{RMSEA}=0.105$

Şekil 2 Dijital Okuryazarlık Ölçeği Birinci Düzey DFA Standartlaştırılmış Çözüm Sonuçları

Şekil 2'de maddelerin solunda yer alan değerler hata varyanslarını göstermektedir. Burada tüm maddelerin hata varyansları küçük olarak değerlendirilebilir. Değerler .15 ile .81 arasındadır. İki sonuca 
göre de maddelerin hatalarının düşük olduğu görülmektedir. DFA'da uyum iyiliği indekslerini de incelemek gerekmektedir. Uyum iyiliği değerleri ile ilgili değerler Tablo 5’te verilmiştir.

Tablo 5 Dijital Okuryazarlık Ölçeği Birinci Düzey DFA Sonuçlarına Ilişkin Uyum İyiliği Değerleri

\begin{tabular}{llll}
\hline iNDEKSLER & $\begin{array}{l}\text { MADDELERE ILIŞKIN } \\
\text { DEĞERLER }\end{array}$ & MÜKEMMEL UYUM & iYi UYUM \\
\hline$\chi^{2}$ & 523.62 & & \\
$\mathrm{Sd}$ & 113 & & \\
$\mathrm{P}$ & 0.0 & & \\
$\chi^{2} / \mathrm{sd}$ & 4.63 & $\chi^{2} / \mathrm{sd} \leq 3.00$ & $3.00<\chi^{2} / \mathrm{sd} \leq 8.00$ \\
RMSEA & 0.11 & $0 \leq \mathrm{RMSEA} \leq .05$ & $.05<\mathrm{RMSEA} \leq .08$ \\
RMSEA (.90 GA) & $1.05-1.48$ & & \\
SRMR & 0.099 & $0 \leq \mathrm{SRMR} \leq .05$ & $.05<\mathrm{SRMR} \leq .10$ \\
GFI & 0.84 & $.95 \leq \mathrm{GFI} \leq 1.00$ & $.90 \leq \mathrm{GFI}<.95$ \\
AGFI & 0.79 & $.90 \leq \mathrm{AGFI} \leq 1.00$ & $.85 \leq \mathrm{AGFI}<.90$ \\
CFI & 0.95 & $.97 \leq \mathrm{CFI} \leq 1.00$ & $.95 \leq \mathrm{CFI}<.97$ \\
NFI & 0.94 & $.95 \leq \mathrm{NFI} \leq 1.00$ & $.90 \leq \mathrm{NFI}<.95$ \\
NNFI & 0.94 & $.97 \leq \mathrm{NNFI} \leq 1.00$ & $.95 \leq \mathrm{NNFI}<.97$ \\
\hline
\end{tabular}

Kaynak: Hu ve Bentler, 1995; Jöroskog ve Sörbom, 1993; Kline, 2005; Steiger, 2007; Sümer, 2000; Tabachnick ve Fidell, 2001'den derlenmiştir.

Tablo 5 incelendiğinde, Dijital Okuryazarlık Ölçeğinde yer alan maddelere ait uyum iyiliği değerlerinin tablonun solunda, alınan ölçüt değerlerin ise tablonun sağdaki iki sütununda yer aldığı görülmektedir. $\chi^{2}$.01 düzeyinde anlamlı bulunmuştur. Bu uyumun olmadığı anlamına gelmektedir ancak örneklem büyüdükçe $\chi^{2}$ anlamlı çıkabilmektedir. Bu yüzden $\chi^{2}$ nin serbestlik derecesine bölümünden elde edilen 4.63 değeri iyi uyumu göstermektedir. NFI, CFI, SRMR iyi uyumu göstermektedir. NFI ve NNFI iyi uyumun hemen altında değerler almışlardır. RMSEA, GFI ve AGFI uyum değerleri ise istenen değerlerden uzaktır. Bütüncül bir değerlendirme yapıldığında Dijital Okuryazarlık Ölçeğinin maddelerinin genel olarak kabul edilebilir uyumu gösterdikleri ifade edilebilir.

Yapı geçerliğini test etmek amacıyla ayrıca ikinci düzey DFA yapılmıştır. İkinci düzey DFA t değerleri Şekil 3'te verilmiştir. 


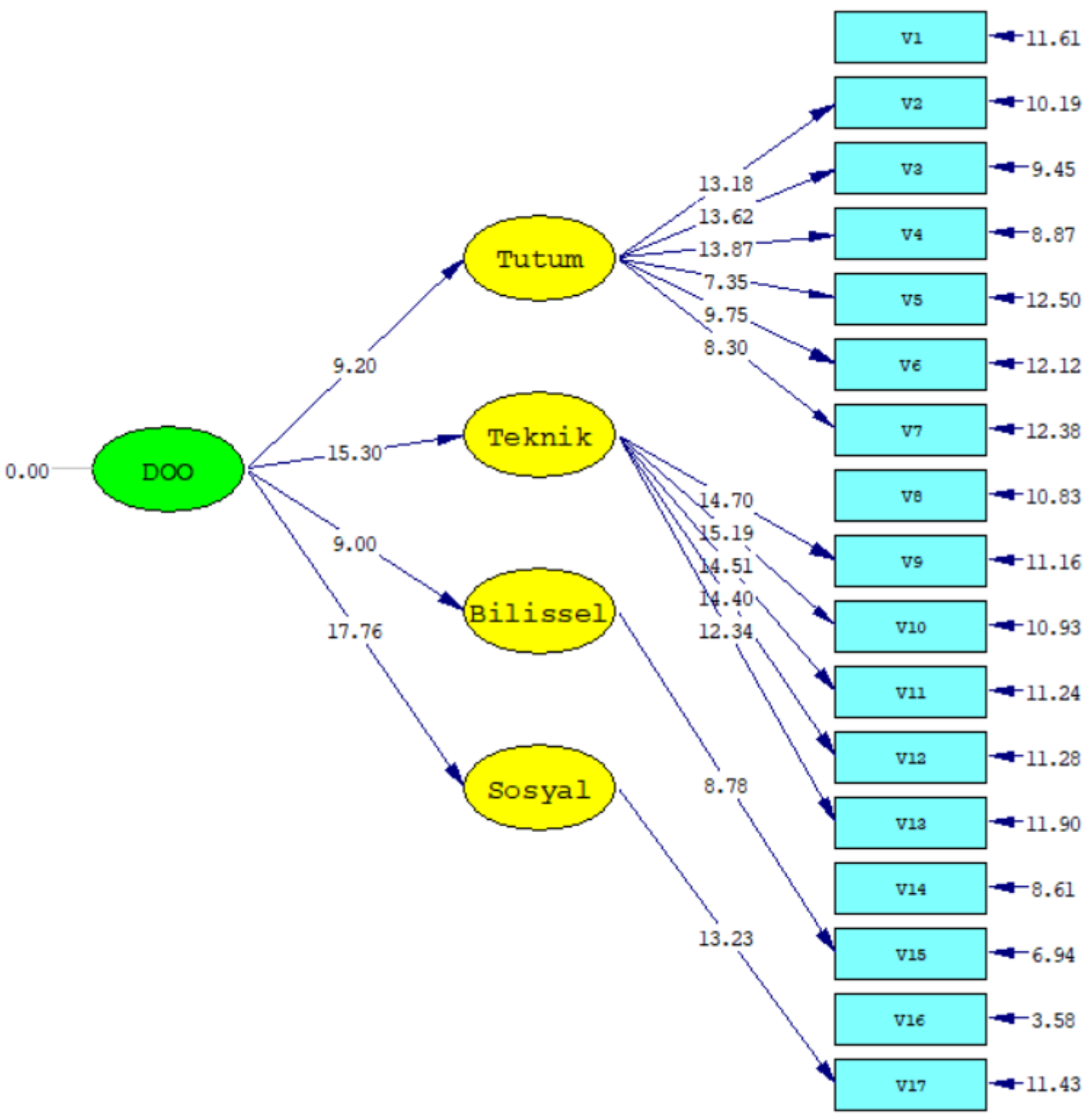

Chi-Square $=597.24, \mathrm{df}=115, \mathrm{P}$-value $=0.00000, \mathrm{RMSEA}=0.113$

Şekil 3 Dijital Okuryazarlık Ölçeği Ikinci Düzey DFA t Değerleri

Şekil 3 incelendiğinde tüm t değerlerinin .01 düzeyinde anlamlı oldukları görülmektedir. Bu gizil değişkenlerin gözlenen değişkenleri doğru bir şekilde açıkladığını göstermektedir. Daha sonra ikinci düzey DFA standart çözüm değerleri incelenmiştir. 


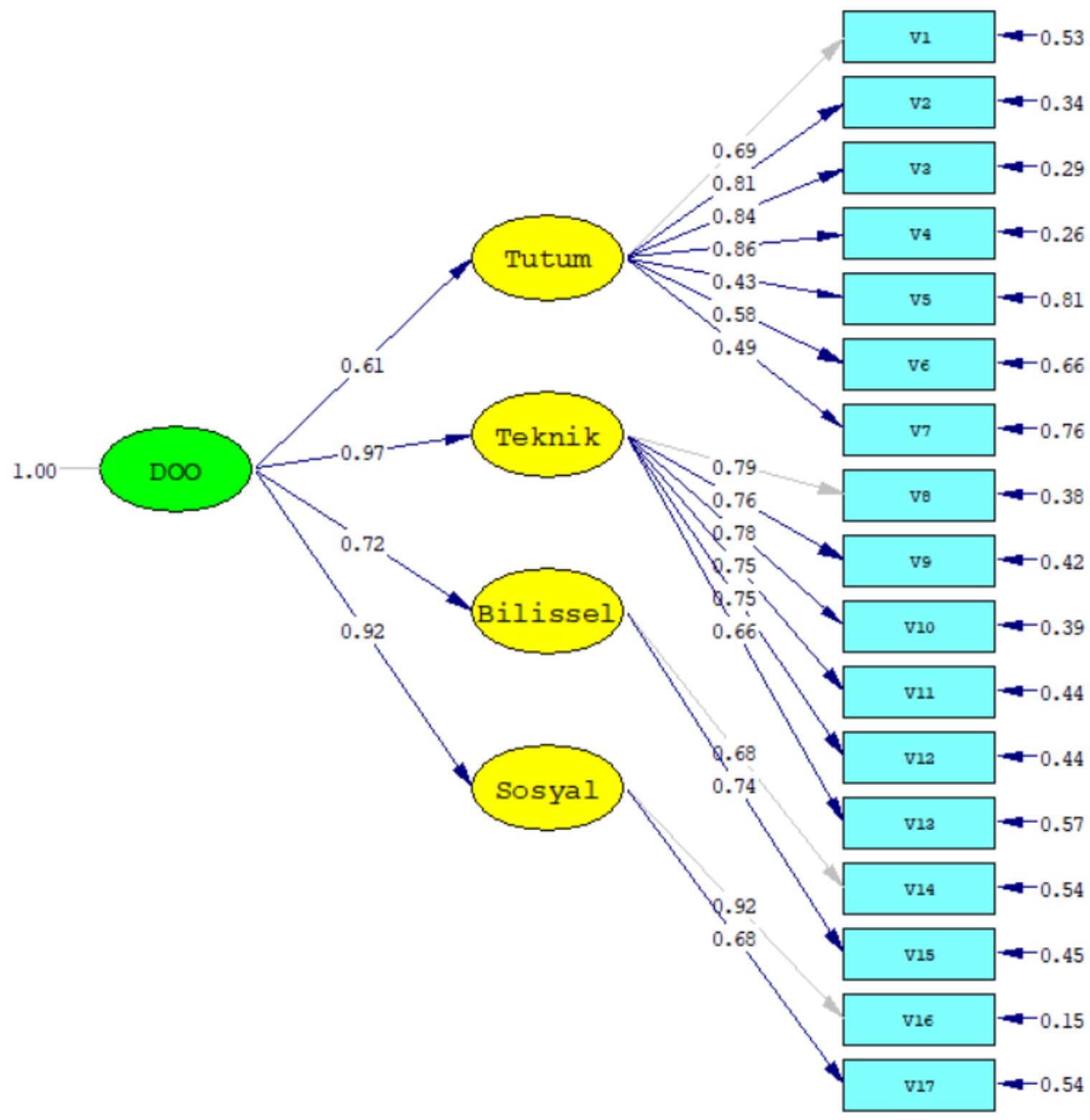

Chi-Square $=597.24, \mathrm{df}=115, \mathrm{P}$-value $=0.00000, \mathrm{RMSEA}=0.113$

Şekil 4 Dijital Okuryazarlık Ölçeği İkinci Düzey DFA Standart Çözüm Değerleri

Şekle göre maddelere ait hatalar düşük olarak ifade edilebilir. Ayrıca uyum iyiliği değerleri incelenmiştir.

Tablo 6 Dijital Okuryazarlık Ölçeği ikinci Düzey DFA Sonuçlarına Iliş̧kin Uyum İyiliği Değerleri

\begin{tabular}{|c|c|c|c|}
\hline INDEKSLER & $\begin{array}{l}\text { MADDELERE íLişKiN } \\
\text { DEĞERLER }\end{array}$ & MÜKEMMEL UYUM & IYi UYUM \\
\hline$\chi^{2}$ & 597.24 & & \\
\hline sd & 115 & & \\
\hline $\mathrm{p}$ & 0.0 & & \\
\hline
\end{tabular}




$\begin{array}{llll}\chi^{2} / \mathrm{sd} & 5.19 & \chi^{2} / \mathrm{sd} \leq 3.00 & 3.00<\chi^{2} / \mathrm{sd} \leq 8.00 \\ \text { RMSEA } & 0.11 & 0 \leq \mathrm{RMSEA} \leq .05 & .05<\mathrm{RMSEA} \leq .08 \\ \text { RMSEA }(.90 \mathrm{GA}) & 0.10-0.12 & & \\ \text { SRMR } & 0.11 & 0 \leq \mathrm{SRMR} \leq .05 & .05<\mathrm{SRMR} \leq .10 \\ \text { GFI } & 0.82 & .95 \leq \mathrm{GFI} \leq 1.00 & .90 \leq \mathrm{GFI}<.95 \\ \text { AGFI } & 0.77 & .90 \leq \mathrm{AGFI} \leq 1.00 & .85 \leq \mathrm{AGFI}<.90 \\ \text { CFI } & 0.94 & .97 \leq \mathrm{CFI} \leq 1.00 & .95 \leq \mathrm{CFI}<.97 \\ \mathrm{NFI} & 0.93 & .95 \leq \mathrm{NFI} \leq 1.00 & .90 \leq \mathrm{NFI}<.95 \\ \mathrm{NNFI} & 0.93 & .97 \leq \mathrm{NNFI} \leq 1.00 & .95 \leq \mathrm{NNFI}<.97\end{array}$

Kaynak: Hu ve Bentler, 1995; Jöroskog ve Sörbom, 1993; Kline, 2005; Steiger, 2007; Sümer, 2000; Tabachnick ve Fidell, 2001'den derlenmiştir.

Tablo 6 incelendiğinde $\chi^{2}$, 01 düzeyinde anlamlı bulunmuştur. Bu uyumun olmadığı anlamına gelmektedir ancak örneklem büyüdükçe $\chi^{2}$ anlamlı çıkabilmektedir. Bu yüzden $\chi^{2}$ nin serbestlik derecesine bölümünden elde edilen 4.26 değeri iyi uyumu göstermektedir. Benzer şekilde NFI de iyi uyumu göstermektedir. CFI, NNFI iyi uyumun hemen altında, RMSEA ve SRMR iyi uyumun hemen üstünde değerler almıştır. GFI ve AGFI ise uyum göstermemektedir. Bütüncül bir değerlendirme yapıldı̆ıında maddelerin ve boyutların kabul edilebilir uyum gösterdiği ifade edilebilir.

Güvenirlik için ölçek toplam ve alt boyutlar için Cronbach'ın alpha katsayısı hesaplanmıştır. Değerler Tablo 7'de verilmiştir.

Tablo 7 Ölçek ve Boyutlarına Iliş̧kin Güvenirlik Değerleri

\begin{tabular}{llllll}
\hline & DOÖ & TUTUM & TEKNIK & BiLişSEL & SOSYAL \\
\hline Cronbach'ın Alphası & .910 & .817 & .865 & .643 & .728 \\
\hline
\end{tabular}

Tablo 7 incelendiğinde ölçeğin güvenirliğinin yüksek olduğu görülmektedir. Boyutlardan da bilişsel hariç diğer boyutların güvenirlik değerleri .70.'in üzerindedir. Bilişsel ise bu değerin altındadır. Madde sayısının az olması sebebiyle güvenirliğin düşük çıktığı düşünülmektedir.

\section{BULGULAR VE YORUM}

Bu bölümde MEB'e bağlı devlet ilkokullarında görev yapan sınıf öğretmenlerinin; cinsiyet, yaş, öğrenim düzeyi, kıdem, günlük internet kullanım süreleri ve günlük dijital araçları kullanım sürelerinin dijital okuryazarlık düzeylerine ilişkin ulaşılan bulgulara yer verilmiştir. 
1)Sınıf öğretmenlerinin dijital okuryazarlık düzeyleri nedir?

Araştırma sorusunun yanıtını bulmak için betimsel istatistikler hesaplanmış ve Tablo 8'de belirtilmiştir.

Tablo 8 Dijital Okuryazarlık Ölçeği ve Ölçeğin Alt Boyutlarına llişkin Betimsel İstatistikler ve Düzeyler

\begin{tabular}{lccccc}
\hline & DOÖ & TUTUM & TEKNIK & BiLişSEL & SOSYAL \\
\hline $\mathrm{N}$ & 329 & 329 & 329 & 329 & 329 \\
$\overline{\mathrm{X}}$ & 68.03 & 28.36 & 23.89 & 8.33 & 7.46 \\
$\mathrm{~S}$ & 8.22 & 3.75 & 3.35 & 1.11 & 1.55 \\
Median & 68 & 28 & 24 & 8 & 8 \\
Minimum & 48 & 17 & 14 & 5 & 4 \\
Maksimum & 85 & 35 & 30 & 10 & 10 \\
Çarpıklık & .14 & -.12 & .00 & -.22 & -.21 \\
Basıklık & -.28 & -.45 & -.01 & .12 & -.47 \\
$\bar{X} / \mathrm{k}$ & 4.00 & 4.05 & 3.98 & 4.17 & 3.73 \\
Düzey & Yüksek & Yüksek & Yüksek & Yüksek & Yüksek \\
\hline
\end{tabular}

k: Madde sayısı

Tablo 8 incelendiğinde katılımcıların kendilerini DOÖ ve alt boyutlarına ilişkin yüksek düzeyde okuryazar olarak gördükleri ifade edilebilir. Katılımcıların kendilerini yüksek düzeyde dijital okuryazar gördükleri ifade edilebilir.

2. Sınıf öğretmenlerinin dijital okuryazarlık düzeyleri

- Cinsiyet

- Yaş

- Öğrenim düzeyine

- Kidem yilına

- Günlük internet kullanım süreleri

- Günlük dijital araçları (akıllı telefon, bilgisayar, tablet veya televizyon vb.) kullanım süresi değişkenlerine göre farklılık göstermekte midir?

Araştırma kapsamında cinsiyete göre farkı incelemek amacı ile ilişkisiz örneklem t testi yapılmıştır. Analiz sonucu Tablo 9'da verilmiştir. 
Tablo 9 Öğretmenlerin DOÖ ve Alt Boyut Puan Ortalamalarının Cinsiyete Göre Karşılaştırılması

\begin{tabular}{llcccccc}
\hline ÖLÇEK/BOYUT & GRUP & $\mathrm{n}$ & $\overline{\mathrm{X}}$ & $\mathrm{S}$ & $\mathrm{Sd}$ & $\mathrm{T}$ & $\mathrm{P}$ \\
\hline \multirow{2}{*}{ DOÖ } & Kadın & 186 & 68,20 & 8,48 & 327 & .43 & .667 \\
& Erkek & 143 & 67,80 & 7,90 & & & \\
Tutum & Kadın & 186 & 28,47 & 3,74 & 327 & .62 & .537 \\
& Erkek & 143 & 28,21 & 3,76 & & & \\
Teknik & Kadın & 186 & 23,85 & 3,48 & 327 & -.20 & .840 \\
& Erkek & 143 & 23,93 & 3,19 & & & \\
Bilişsel & Kadın & 186 & 8,39 & 1,09 & 327 & 1.19 & .233 \\
& Erkek & 143 & 8,24 & 1,15 & & & \\
\multirow{3}{*}{ Sosyal } & Kadın & 186 & 7,48 & 1,57 & 327 & .37 & .709 \\
& Erkek & 143 & 7,42 & 1,53 & & & \\
\hline
\end{tabular}

Tablo 9 incelendiğinde DOÖ ve alt boyutları için puan ortalamalarının cinsiyete göre anlamlı bir farklılaşma görülmemiş̧tir. ( $p>$.05). Bu sonuca göre kadın öğretmen ve erkek öğretmenler benzer düzeyde dijital okuryazarlığa sahip olduklarını düşünmektedirler.

Yaşa göre fark incelenirken öncelikle kategori birleştirilmiş yeni kategoriler 20-30, 31-40 ve 41 ve üzeri şeklinde olmuştur. Betimsel istatistik sonuçları Tablo 10'da ANOVA sonucu ise Tablo 11'de belirtilmiştir.

Tablo 10 DOÖ ve Alt Boyut Ortalamalarının Yaşa Göre Karşılaştııılması

\begin{tabular}{llrrr}
\hline & YAŞ & $n$ & $\bar{X}$ & $\mathrm{~S}$ \\
\hline DOÖ & $20-30$ & 131 & 69,11 & 8,12 \\
& $31-40$ & 110 & 68,52 & 8,00 \\
\multirow{3}{*}{ Tutum } & 41 ve üzeri & 88 & 65,81 & 8,31 \\
& $20-30$ & 131 & 28,70 & 3,89 \\
& $31-40$ & 110 & 28,33 & 3,59 \\
\multirow{2}{*}{ Teknik } & 41 ve üzeri & 88 & 27,88 & 3,71 \\
& $20-30$ & 131 & 24,44 & 3,25 \\
& $31-40$ & 110 & 24,20 & 3,24 \\
Bilişsel & 41 ve üzeri & 88 & 22,67 & 3,37 \\
& $20-30$ & 131 & 8,34 & 1,09 \\
& $31-40$ & 110 & 8,44 & 1,10 \\
\multirow{3}{*}{ Sosyal } & 41 ve üzeri & 88 & 8,18 & 1,16 \\
& $20-30$ & 131 & 7,63 & 1,50 \\
& $31-40$ & 110 & 7,55 & 1,54 \\
\hline
\end{tabular}


Tabloya göre DOÖ ve alt boyutlarına ilişkin puan ortalamaları farklı yaşlarda farklı değerler almıştır. Ancak sadece bu değerlere göre karar verilmemektedir. ANOVA sonuçlarını incelemek gerekmektedir.

Tablo 11 Öğretmenlerin DOÖ ve Alt Boyut Puan Ortalamalarının Yaşa Göre ANOVA Sonuçları

\begin{tabular}{|c|c|c|c|c|c|c|c|}
\hline & VARYANSIN KAYNAĞI & $\begin{array}{l}\text { KARELER } \\
\text { TOPLAMI }\end{array}$ & sd & $\begin{array}{l}\text { KARELER } \\
\text { ORTALAMASI }\end{array}$ & $\mathrm{F}$ & $\mathrm{p}$ & $\begin{array}{l}\text { ANLAMLI } \\
\text { FARK }\end{array}$ \\
\hline \multirow{3}{*}{ DOÖ } & Gruplar Arası & 613,070 & 2 & 306,535 & 4,635 & , 010 & $20-30,41$ \\
\hline & Gruplar İçi & 21557,683 & 326 & 66,128 & & & \\
\hline & Toplam & 22170,754 & 328 & & & & \\
\hline \multirow{3}{*}{ Tutum } & Gruplar Arası & 36,160 & 2 & 18,080 & 1,291 & ,277 & \\
\hline & Gruplar İçi & 4567,232 & 326 & 14,010 & & & \\
\hline & Toplam & 4603,392 & 328 & & & & \\
\hline \multirow{3}{*}{ Teknik } & Gruplar Arası & 181,475 & 2 & 90,738 & 8,439 &, 000 & $\begin{array}{c}20-30,41 \\
. .\end{array}$ \\
\hline & Gruplar İçi & 3505,364 & 326 & 10,753 & & & $\begin{array}{c}31-40,41 \\
. .\end{array}$ \\
\hline & Toplam & 3686,839 & 328 & & & & \\
\hline \multirow{3}{*}{ Bilişsel } & Gruplar Arası & 3,180 & 2 & 1,590 & 1,285 & 278 & \\
\hline & Gruplar İçi & 403,367 & 326 & 1,237 & & & \\
\hline & Toplam & 406,547 & 328 & & & & \\
\hline \multirow{3}{*}{ Sosyal } & Gruplar Arası & 17,323 & 2 & 8,662 & 3,675 &, 026 & $\begin{array}{c}20-30,41 \\
. .\end{array}$ \\
\hline & Gruplar İçi & 768,288 & 326 & 2,357 & & & \\
\hline & Toplam & 785,611 & 328 & & & & \\
\hline
\end{tabular}

Yapılan analiz sonucuna göre öğretmenlerin DOÖ $\left[F_{(2-326)}=4.635, \mathrm{p}<.05\right]$, Teknik $\left[\mathrm{F}_{(2-326)}=8.439\right.$, $\mathrm{p}<.05]$ ve Sosyal $\left[\mathrm{F}_{(2-326)}=3.675, \mathrm{p}<.05\right]$ puan ortalamaları yaşlarına göre anlamlı farklıık göstermektedir. Ölçek ve iki alt boyut için 20-30 yaşındakilerin puan ortalamaları 41 ve üzeri yaşındakilerden daha yüksektir. Teknik için 31-40 yaşındakilerin ortalamaları da 41 ve üzerindekilerin ortalamalarından daha yüksektir. Ölçek, teknik ve sosyal boyutlar için yaş arttıkça okuryazarlık düzeyi azalmaktadır. Tutum $\left[\mathrm{F}_{(2-326)}=1.291, \mathrm{p}>.05\right]$ ve Bilişsel $\left[\mathrm{F}_{(2-326)}=1.285, \mathrm{p}>.05\right]$ boyutlar için ise yaşa göre anlamlı farklılık bulunmamıştır.

Öğrenim düzeyine göre farkı incelemeden önce kategori birleştirilmiş ve yeni kategoriler ön lisans/lisans ve lisansüstü olarak gerçekleşmiştir. Analiz sonuçları Tablo 12'de belirtilmiştir. 
Tablo 12 Öğretmenlerin DOÖ ve Alt Boyut Puan Ortalamalarının Öğrenim Düzeyine Göre Karşılaştııılması

\begin{tabular}{llrlrrrr}
\hline ÖLÇEK/BOYUT & GRUP & $\mathrm{n}$ & $\overline{\mathrm{X}}$ & $\mathrm{S}$ & $\mathrm{Sd}$ & $\mathrm{T}$ & $\mathrm{P}$ \\
\hline DOÖ & Lisans & 289 & 67,45 & 8,03 & 327 & -3.48 & .001 \\
& Lisansüstü & 40 & 72,20 & 8,50 & & & \\
Tutum & Lisans & 289 & 28,24 & 3,73 & 327 & -1.52 & .128 \\
& Lisansüstü & 40 & 29,20 & 3,81 & & & \\
Teknik & Lisans & 289 & 23,62 & 3,28 & 327 & -3.99 & .000 \\
& Lisansüstü & 40 & 25,83 & 3,30 & & & \\
Bilişsel & Lisans & 289 & 8,27 & 1,08 & 327 & -2.58 & .010 \\
& Lisansüstü & 40 & 8,75 & 1,26 & & & \\
Sosyal & Lisans & 289 & 7,32 & 1,51 & 327 & -4.34 & .000 \\
& Lisansüstü & 40 & 8,43 & 1,47 & & & \\
\hline
\end{tabular}

Tablo 12 incelendiğinde DOÖ $(t(327)=-3.48, p<.05)$, Teknik $(t(327)=-3.99, p<.05)$, Bilişsel $(\mathrm{t}(327)=-2.58, \mathrm{p}<.05)$ ve Sosyal $(\mathrm{t}(327)=-4.34, \mathrm{p}<.05)$ alt boyutları için puan ortalamalarının öğrenim düzeyine göre anlamlı bir farklılık gösterdiği görülmektedir. Ölçek ve belirtilen alt boyutlar için lisansüstü eğitime sahip olanların okuryazarlık düzeyleri ön lisans / lisans mezunlarından daha yüksektir. Tutum boyutu için anlamlı farklılık bulunmamıştır $(\mathrm{t}(327)=-1.52, \mathrm{p}>.05)$

Kıdeme göre farklılık olup olmadığını incelemek amacıyla ANOVA yapılmıştır. Analiz sonucu betimsel istatistikler Tablo 13 ve ANOVA sonucu Tablo 14'te belirtilmiştir.

Tablo 13 DOÖ ve Alt Boyut Ortalamalarının Kıdeme Göre Betimsel İstatistikleri

\begin{tabular}{llrcc}
\hline & KIDEM & $\mathrm{n}$ & $\overline{\mathrm{X}}$ & \\
\hline DOÖ & $0-5$ & 119 & 69,40 & 8,74 \\
& $6-10$ & 45 & 68,67 & 8,17 \\
& $11-15$ & 49 & 68,51 & 7,79 \\
& $16-20$ & 44 & 66,66 & 3,91 \\
& $21-25$ & 30 & 64,47 & 3,53 \\
& 26 yIl ve & 42 & 66,86 & 3,85 \\
& $0-5$ & 119 & 28,84 & 3,53 \\
Tutum & $6-10$ & 45 & 28,80 & 3,34 \\
& $11-15$ & 49 & 28,20 & 3,20 \\
& $16-20$ & 44 & 27,50 & 1,03 \\
& $21-25$ & 30 & 27,30 & 1,11 \\
& 26 yıl ve & 42 & 28,33 & 1,18 \\
& $0-5$ & 119 & 24,56 & 1,60 \\
& $6-10$ & 45 & 24,02 & 1,59 \\
\hline
\end{tabular}




\begin{tabular}{rlrrl}
\hline & $16-20$ & 44 & 23,57 & 8,74 \\
& $21-25$ & 30 & 22,10 & 8,17 \\
& 26 y.l ve & 42 & 23,05 & 7,79 \\
& $0-5$ & 119 & 8,36 & 3,91 \\
\multirow{5}{*}{ Bilişsel } & $6-10$ & 45 & 8,42 & 3,53 \\
& $11-15$ & 49 & 8,33 & 3,85 \\
& $16-20$ & 44 & 8,32 & 3,53 \\
& $21-25$ & 30 & 8,17 & 3,34 \\
& 26 y.l ve & 42 & 8,26 & 3,20 \\
Sosyal & $0-5$ & 119 & 7,64 & 1,03 \\
& $6-10$ & 45 & 7,42 & 1,11 \\
& $11-15$ & 49 & 7,76 & 1,18 \\
& $16-20$ & 44 & 7,27 & 1,60 \\
& $21-25$ & 30 & 6,90 & 1,59 \\
& 26 y.l ve & 42 & 7,21 & 1,42 \\
\hline
\end{tabular}

Tabloya göre DOÖ ve alt boyutlarına ilişkin puan ortalamaları kıdeme göre farklı değerler almıştır. Ancak sadece bu değerlere göre karar verilmemektedir. ANOVA sonuçlarını incelemek gerekmektedir.

Tablo 14 Öğretmenlerin DOÖ ve Alt Boyut Puan Ortalamalarının Kıdeme Göre ANOVA Sonuçları

\begin{tabular}{|c|c|c|c|c|c|c|c|}
\hline & VARYANSIN KAYNAĞI & $\begin{array}{l}\text { KARELER } \\
\text { TOPLAMI }\end{array}$ & sd & $\begin{array}{l}\text { KARELER } \\
\text { ORTALAMASI }\end{array}$ & $\mathrm{F}$ & $\mathrm{p}$ & $\begin{array}{l}\text { ANLAMLI } \\
\text { FARK }\end{array}$ \\
\hline & Gruplar Arası & 775,374 & 5 & 155,075 & 2,341 &, 041 & $0-5,21-$ \\
\hline \multirow[t]{3}{*}{ DOÖ } & Gruplar İçi & 21395,379 & 323 & 66,240 & & & $6-10,21-$ \\
\hline & Toplam & 22170,754 & 328 & & & & $11-15$ \\
\hline & Gruplar Arası & 103,633 & 5 & 20,727 & 1,488 & 193 & \\
\hline \multirow[t]{3}{*}{ Tutum } & Gruplar İçi & 4499,759 & 323 & 13,931 & & & \\
\hline & Toplam & 4603,392 & 328 & & & & \\
\hline & Gruplar Arası & 190,653 & 5 & 38,131 & 3,523 &, 004 & $0-5,21-$ \\
\hline \multirow[t]{3}{*}{ Teknik } & Gruplar İçi & 3496,186 & 323 & 10,824 & & & \\
\hline & Toplam & 3686,839 & 328 & & & & \\
\hline & Gruplar Arası & 1,500 & 5 & ,300 & ,239 & 945 & \\
\hline \multirow[t]{3}{*}{ Bilişsel } & Gruplar İçi & 405,047 & 323 & 1,254 & & & \\
\hline & Toplam & 406,547 & 328 & & & & \\
\hline & Gruplar Arası & 21,611 & 5 & 4,322 & 1,827 &, 107 & \\
\hline \multirow[t]{2}{*}{ Sosyal } & Gruplar İçi & 764,000 & 323 & 2,365 & & & \\
\hline & Toplam & 785,611 & 328 & & & & \\
\hline
\end{tabular}

Yapılan analiz sonucuna göre öğretmenlerin DOÖ $[F(5-323)=2.341, \mathrm{p}<.05]$ ve Teknik $[F(5-323)$ = 3.523, $\mathrm{p}$ <.05] puan ortalamaları kıdeme göre anlamlı farklıık göstermektedir. Ölçek için 21-25 yıl 
kıdemi olanların puan ortalamaları; 0-5, 6-10 ve 11-15 yıl kıdemi olanlara göre daha düşüktür. Teknik boyut için ise 21-25 yıl kıdemi olanların ortalamaları 0-5 yıl kıdemi olanlardan daha düşüktür. Tutum $[F(5-323)=1.488, p>.05]$, Bilişsel $[F(5-323)=.239, p>.05]$ ve Sosyal $[F(5-323)=1.827, p>.05]$ boyutlarından elde edilen puan ortalamaları kıdeme göre farklılaşmamaktadır.

Günlük internet kullanımına göre farklılık olup olmadığını incelemek amacıyla öncelikle kategori birleştirilmiştir. Yeni kategoriler 3 saate kadar, 4-5 saat ve 6 saat ve üzeri şeklinde gerçekleşmiştir. Daha sonra fark olup olmadığını belirlemek amacıyla ANOVA yapılmıştır. Analiz sonucu betimsel istatistikler Tablo 15 'te ve ANOVA sonucu Tablo 16'da verilmiştir.

Tablo 15 DOÖ ve Alt Boyut Ortalamalarının İnternet Kullanımına Göre Betimsel İstatistikleri

\begin{tabular}{lllll}
\hline & iNTERNET KULLANIMI & & & S \\
\hline DOÖ & 3 saate kadar & 96 & 66,99 & 8,74 \\
& 4-5 saat & 123 & 68,43 & 8,17 \\
\multirow{4}{*}{ Tutum } & 6 saat ve üzeri & 110 & 68,48 & 7,79 \\
& 3 saate kadar & 96 & 28,03 & 3,91 \\
& 4-5 saat & 123 & 28,62 & 3,53 \\
\multirow{3}{*}{ Teknik } & 6 saat ve üzeri & 110 & 28,35 & 3,85 \\
& 3 saate kadar & 96 & 23,51 & 3,53 \\
& 4-5 saat & 123 & 23,93 & 3,34 \\
Bilişsel & 6 saat ve üzeri & 110 & 24,17 & 3,20 \\
& 3 saate kadar & 96 & 8,23 & 1,03 \\
& 4-5 saat & 123 & 8,45 & 1,11 \\
\multirow{3}{*}{ Sosyal } & 6 saat ve üzeri & 110 & 8,28 & 1,18 \\
& 3 saate kadar & 96 & 7,22 & 1,60 \\
& 4-5 saat & 123 & 7,44 & 1,59 \\
& 6 saat ve üzeri & 110 & 7,68 & 1,42 \\
\hline
\end{tabular}

Tabloya göre DOÖ ve alt boyutlarına ilişkin puan ortalamaları internet kullanım farklı değerler almıştır. Ancak sadece bu değerlere göre karar verilmemektedir. ANOVA sonuçlarını incelemek gerekmektedir.

Tablo 16 Öğretmenlerin DOÖ ve Alt Boyut Puan Ortalamalarının İnternet Kullanım Süresine Göre ANOVA

\begin{tabular}{|c|c|c|c|c|c|c|c|}
\hline \multicolumn{8}{|c|}{ Sonuçları } \\
\hline & VARYANSIN KAYNAĞI & $\begin{array}{l}\text { KARELER } \\
\text { TOPLAMI }\end{array}$ & sd & $\begin{array}{l}\text { KARELER } \\
\text { ORTALAMASI }\end{array}$ & $F$ & $\mathrm{p}$ & $\begin{array}{l}\text { ANLAMLI } \\
\text { FARK }\end{array}$ \\
\hline \multirow{3}{*}{ DOÖ } & Gruplar Arası & 146,138 & 2 & 73,069 & 1,082 & ,340 & \\
\hline & Gruplar İçi & 22024,616 & 326 & 67,560 & & & \\
\hline & Toplam & 22170,754 & 328 & & & & \\
\hline Tutum & Gruplar Arası & 18,572 & 2 & 9,286 & ,660 &, 517 & \\
\hline
\end{tabular}




\begin{tabular}{|c|c|c|c|c|c|c|}
\hline & Gruplar İçi & 4584,820 & 326 & 14,064 & & \\
\hline & Toplam & 4603,392 & 328 & & & \\
\hline \multirow{4}{*}{ Teknik } & Gruplar Arası & 22,790 & 2 & 11,395 & 1,014 & ,364 \\
\hline & Gruplar İçi & 3664,049 & 326 & 11,239 & & \\
\hline & Toplam & 3686,839 & 328 & & & \\
\hline & Gruplar Arası & 2,919 & 2 & 1,459 & 1,179 & ,309 \\
\hline \multirow[t]{3}{*}{ Bilişsel } & Gruplar İçi & 403,628 & 326 & 1,238 & & \\
\hline & Toplam & 406,547 & 328 & & & \\
\hline & Gruplar Arası & 11,048 & 2 & 5,524 & 2,325 & ,099 \\
\hline \multirow[t]{2}{*}{ Sosyal } & Gruplar İçi & 774,563 & 326 & 2,376 & & \\
\hline & Toplam & 785,611 & 328 & & & \\
\hline
\end{tabular}

Yapılan analiz sonucuna göre öğretmenlerin DOÖ ve alt boyutlarına ilişkin puan ortalamaları günlük internet kullanım süresine göre farklılaşmamaktadır ( $p>$.05). Buna göre az ya da çok internet kullanan öğretmenler benzer düzeyde dijital okuryazarlık puanına sahiptir.

Günlük dijital araç kullanımına göre farklılık olup olmadığını incelemek amacıyla öncelikle kategori birleştirilmiştir. Yeni kategoriler 3 saate kadar, 4-5 saat ve 6 saat ve üzeri şeklinde gerçekleşmiştir. Daha sonra fark olup olmadığını belirlemek amacıyla ANOVA yapılmıştır. Analiz sonucu betimsel istatistikler Tablo 17 ve ANOVA sonucu Tablo 18'de verilmiştir.

Tablo 17 DOÖ ve Alt Boyut Ortalamalarının Dijital Araç Kullanımına Göre Betimsel İstatistikleri

\begin{tabular}{llrrr}
\hline & DijiTAL ARAÇ KULLANIMI & $n$ & & S \\
\hline \multirow{2}{*}{ DOÖ } & 3 saate kadar & 88 & 67,97 & 8,97 \\
& 4-5 saat & 112 & 67,93 & 8,36 \\
\multirow{4}{*}{ Tutum } & 6 saat ve üzeri & 129 & 68,16 & 7,61 \\
& 3 saate kadar & 88 & 28,47 & 3,72 \\
& 4-5 saat & 112 & 28,29 & 3,85 \\
\multirow{3}{*}{ Teknik } & 6 saat ve üzeri & 129 & 28,34 & 3,69 \\
& 3 saate kadar & 88 & 23,80 & 3,72 \\
& 4-5 saat & 112 & 23,86 & 3,25 \\
\multirow{3}{*}{ Bilişsel } & 6 saat ve üzeri & 129 & 23,98 & 3,20 \\
& 3 saate kadar & 88 & 8,39 & 0,96 \\
& 4-5 saat & 112 & 8,30 & 1,18 \\
\multirow{3}{*}{ Sosyal } & 6 saat ve üzeri & 129 & 8,31 & 1,15 \\
& 3 saate kadar & 88 & 7,32 & 1,69 \\
& 4-5 saat & 112 & 7,48 & 1,51 \\
& 6 saat ve üzeri & 129 & 7,53 & 1,48 \\
\hline
\end{tabular}


Tabloya göre DOÖ ve alt boyutlarına ilişkin puan ortalamaları farklı saat dijital araç kullanımı farklı değerler almıştır. Ancak sadece bu değerlere göre karar verilmemektedir. ANOVA sonuçlarını incelemek gerekmektedir.

Tablo 18 Öğretmenlerin DOÖ ve Alt Boyut Puan Ortalamalarının Dijital Araç Kullanım Süresine Göre ANOVA Sonuçları

\begin{tabular}{|c|c|c|c|c|c|c|c|}
\hline & VARYANSIN KAYNAĞI & $\begin{array}{l}\text { KARELER } \\
\text { TOPLAMI }\end{array}$ & sd & $\begin{array}{l}\text { KARELER } \\
\text { ORTALAMASI }\end{array}$ & $\mathrm{F}$ & $\mathrm{p}$ & $\begin{array}{l}\text { ANLAMLI } \\
\text { FARK }\end{array}$ \\
\hline \multirow{3}{*}{ DOÖ } & Gruplar Arası & 3,528 & 2 & 1,764 & ,026 & 974 & \\
\hline & Gruplar İçi & 22167,226 & 326 & 67,998 & & & \\
\hline & Toplam & 22170,754 & 328 & & & & \\
\hline \multirow{3}{*}{ Tutum } & Gruplar Arası & 1,645 & 2 &, 822 & ,058 & 943 & \\
\hline & Gruplar İçi & 4601,747 & 326 & 14,116 & & & \\
\hline & Toplam & 4603,392 & 328 & & & & \\
\hline \multirow{3}{*}{ Teknik } & Gruplar Arası & 1,876 & 2 & ,938 & ,083 & 920 & \\
\hline & Gruplar İçi & 3684,963 & 326 & 11,304 & & & \\
\hline & Toplam & 3686,839 & 328 & & & & \\
\hline \multirow{3}{*}{ Bilişsel } & Gruplar Arası & ,408 & 2 & 204 & , 164 & 849 & \\
\hline & Gruplar içci & 406,139 & 326 & 1,246 & & & \\
\hline & Toplam & 406,547 & 328 & & & & \\
\hline \multirow{3}{*}{ Sosyal } & Gruplar Arası & 2,401 & 2 & 1,200 &, 500 & ,607 & \\
\hline & Gruplar İçi & 783,210 & 326 & 2,402 & & & \\
\hline & Toplam & 785,611 & 328 & & & & \\
\hline
\end{tabular}

Yapılan analiz sonucuna göre öğretmenlerin DOÖ ve alt boyutlarına ilişkin puan ortalamaları günlük dijital araç kullanım süresine göre farkıılaşmamaktadır ( $p$ > .05). Buna göre az ya da çok dijital araç kullanan öğretmenler benzer düzeyde dijital okuryazarlık puanına sahiptir.

\section{SONUÇ}

Bu araştırmada MEB'e bağlı devlet ilkokullarında görevini yapmakta olan sınıf öğretmenlerinin dijital okuryazarlık düzeylerinin incelenmesi amaçlanmıştır. Araştırmanın amacı doğrultusunda tarama modeli kullanılarak alt problemlere yönelik cevaplar aranmıştır. Araştırmada sınıf öğretmenlerinin; cinsiyet, yaş, kıdem, öğrenim düzeyi, günlük interneti kullanma süresi ve günlük dijital araçları kullanım süreleri değişkenlerine ilişkin dijital okuryazarlık düzeyleri incelenmiştir. 
Araştırmada kullanılan DOÖ öğretmen adaylarına yönelik geliştirildiği için alanyazındaki çalışmalar öğretmen adayları üzerinde gerçekleştirilmiştir ancak DOÖ ilk kez bu araştırmada öğretmenlerle uygulanmıştır. Bu nedenle araştırmanın sonuçları, alanyazında yer alan öğretmenlere yönelik teknoloji okuryazarlığı düzeyleri üzerine yapılmış olan araştırma sonuçları ile ilişkilendirilmiştir. Araştırmanın bulgularına göre sınıf öğretmenlerinin kendilerine yönelik dijital okuryazarlık düzeylerinin yüksek olduğu sonucuna ulaşılmıştır. Bu sonuçtan farklı olarak öğretmen adaylarının dijital okuryazarlık düzeyleri karşılaştırıldığında Boyacı'nın çalışmasında kısmen yüksek olduğu, Çetin ise yeterli seviyede olduğu sonucuna ulaşmışlardır (2019; 2016). Araştırmadan elde edilen sonuçların farklılık göstermesi çalışmaların farklı gruplara farkı zamanlarda uygulandığı için olduğu düşünülebilir. Alanyazında öğretmenlerin teknoloji okuryazarlığına yönelik çalışmalar incelendiğinde sınıf öğretmenlerinin bilgisayar teknolojilerini ve internet tabanlı uygulamaları yeteri kadar kullanmadıkları ve bu sebeple teknoloji kullanımında istenilen yeterlikte olmadıkları sonucuna ulaşılmıştır (Ulaş \& Ozan, 2010). BiT kullanımına yönelik öğretmenler ile yapılmış başka bir çalışmada da öğretmenlerin öğretim teknolojilerine yönelik önemli derece eksiklikleri olduğu bulgusuna ulaşılmıştır (Hakkari, Tüysüz, \& Atalar, 2016). Öğretmenlerin teknoloji kullanımlarına ilişkin çalışmalar incelendiğinde Güneş ve Buluç; öğretmenlerin, sınıflarını dijital araçlar ile zenginleştirmelerini, dijital araçları eğitsel amaçlara uygun kullanmalarını ve dijital araçların kullanım yeterliğine sahip olup kendilerini geliştirmeleri gerektiğini ifade etmişlerdir (2017).

Araştırmanın bulguları incelendiğinde sınıf öğretmenlerinin dijital okuryazarlık düzeylerinin cinsiyet değişkenine göre anlamlı bir farklılık görülmemiştir. Çalışmaya katılan erkek sınıf öğretmenleri ile kadın sınıf öğretmenlerinin dijital okuryazarlık düzeylerinin benzer olduğu sonucuna ulaşılmıştır. Öğretmen adayları ile yürütülen çalışmalar incelendiğinde dijital okuryazarlık düzeyleri, erkek öğretmen adaylarının kadınlara göre daha yüksek olduğu görülmüştür (Çetin, 2016). Alanyazında öğretmenlerin dijital okuryazarlık düzeyleri incelenmediği için öğretmenlerin internet tabanlı teknolojileri kullanım düzeylerine yönelik çalışmalar ile ilişki kurulmuştur. Ulaş ve Ozan çalışmalarında öğretmenlerin internet tabanlı teknoloji kullanımları ile cinsiyete göre önemli bir fark olmadığı sonucuyla paralellik göstermektedir (2010). Ayrıca aday öğretmenlerin dijital okuryazarlık düzeyleri üzerine yapılan çalışmalarda da cinsiyet değişkeni üzerinden anlamlı farklılık bulunmamıştır (Sulak, 2019; Yazıcıoğlu, Yaylak, \& Genç, 2020; Yontar, 2019) 
Araştırmada incelenen diğer bir değişken ise öğretmenlerin yaşları ile dijital okuryazarlık düzeyleri arasındaki ilişkidir. Sınıf öğretmenlerinin yaşları arttıkça dijital okuryazarlık düzeylerinde azalma olduğu sonucuna ulaşılmıştır. Çocukların ve gençlerin dijital ortamlarda daha fazla etkileşime girdikleri ve teknolojinin içinde büyümeleri göz önünde bulundurulduğunda, ebeveynlerin ve görev yapmakta olan öğretmenlerin ise dijital teknoloji becerilerinin çocuklara kıyasla daha düşük düzeyde olduğu varsayılmaktadır (T.C. Milli Eğitim Bakanlığı, 2020). Hayatının ilerleyen yaşlarında teknolojiyle tanışmış ve teknolojiye maruz kalan yetişkinlerin teknolojiye yönelik uyum göstermede sorun yaşadıkları, teknolojinin içerisinde doğan ve teknolojiyle yetişen çocukların ve gençlerin teknolojiye çok hızlı şekilde uyum sağladıkları görülmektedir (Karakuş Yılmaz, 2020). Dijital yerli ve dijital göçmen olarak adlandırılan ayrımda yaş önemli bir kriterdir (Prensky, 2001). Bazı araştırmalar, yaşın önemli ve ters bir şekilde dijital akıcılıkla ilişkili olduğunu göstermektedir (Li \& Ranieri, 2010; Salajan, Schönwetter, \& Cleghorn, 2010). Bu çalışmada sınıf öğretmenlerinin, dijital araçları ve interneti kullandıkları sonucuna ulaşılmakla birlikte, 21-30 yaş aralığındaki öğretmenlerin dijital okuryazarlıklarının yüksek olduğu, yaş arttıkça okuryazarlık düzeyinin azaldığı görülmüştür. Bunun sebebi yaş düzeyi yüksek olan öğretmenlerin genç öğretmenlere göre teknoloji ve dijital araçlarla geç tanışması, alışkanlıklarını terk etmekte zorlanmaları olarak açıklanabilir (Güder \& Demir, 2018). Akkoyunlu sınıf öğretmenlerinin ve 40 yaş üzerindeki öğretmenlerin hiç internet kullanmadıkları sonucuna ulaşmıştır (2002). Bu durumun nedeni olarak da geçen zaman içerisinde internet ve dijital araçların gelişmesi, ekonomik olarak ulaşılabilir olması, yaygınlaşması ve pandeminin etkisiyle uzaktan eğitime geçiş olduğu düşünülebilir. Ulaş ve Ozan'ın yapmış oldukları çalışmada yaşı büyük olan öğretmenlerin klasik eğitim teknolojilerinden vazgeçmedikleri ve sınıf içi öğretim etkinliklerinde internet temelli teknoloji kullanımında yaş faktörünün belirleyici olmadığı sonucuna ulaşmışlardır (2010). Öğretmenlerin dijital okuryazarlık düzeyleri ile teknoloji kullanımları ilişkilendirildiğinde Akkoyunlu 21- 35 yaş aralığındaki öğretmenlerin teknolojiyi daha fazla kullandığını belirtmiştir (2002).

Araştırma sınıf öğretmenlerinin dijital okuryazarlık düzeyleri ile kıdemleri arasında anlamlı farklılık olduğu görülmüştür. Öğretmenlerin dijital okuryazarlık düzeylerinin yaşa ilişkin sonucu ile kıdemlerine yönelik elde edilen bulgular paralellik göstermektedir. 21- 25 yıl kıdemi olanların diğer kıdemdeki öğretmenlerle kıyaslandığında dijital okuryazarlık düzeylerinin daha düşük olduğu sonucuna ulaşıımıştır. Sur, eğitimde yeni teknolojik araçları kullanan öğretmenlerin 1-20 yıl aralığındaki kıdeme 
sahip öğretmenler olduğu, 20 yıl ve üzeri kıdemdeki öğretmenlerin klasik teknolojileri kullanmaya devam ettiğini belirtmiştir (2012). Özerbaş ve Güneş'e göre derslerde eğitim teknolojilerini, düşük kıdeme sahip öğretmenlerin daha başarılı şekilde kullandıklarını belirtmişlerdir (2015). Çalışmada elde edilen bulguların aksine Ulaş ve Ozan yaptıkları çalışmada öğretmenlerin kıdemleri arttıkça eğitim teknolojilerini daha fazla kullandıkları sonucuna ulaşmışlardır (2010). Güneş ve Buluç'un çalışmasında sınıf öğretmenlerinin kıdemleri ile teknolojiyi kullanımları arasında fark görülmemiş̧tir (2017). Barut çalışmasında mesleki kıdem ile eğitimde teknoloji kullanımı arasında anlamlı fark olmadığı bulgusuna ulaşmıştır (2015). Bu sonuçlardan hareketle mesleğe yeni başlayan genç öğretmenlerin teknoloji ve dijital araçlara yönelik okuryazarlık bilgi ve becerilerinin yüksek olduğu ancak sahip oldukları bu becerileri eğitim öğretim ortamına aktarmada yeterli olmadıkları düşünülebilir (Güneş \& Buluç, 2017).

Araştırma sonuçlarından yola çıkarak, sınıf öğretmenlerinin, derslerini dijital araçlarla zenginleştirmeleri, araç tercihi yapabilmeleri adına ve dijital araçları teknik anlamda kullanabilmeleri, özellikle öğretime yönelik öğrencilerin seviyelerine uygun içerik geliştirme adına öğretmenlerin dijital okuryazarlık düzeylerini geliştirmeye yönelik kapsamlı eğitim projeleri geliştirilebilir. Bu araştırmada öğretmenliklere yönelik bir dijital okuryazarlık ölçeği bulunmaması nedeniyle kullanılan dijital okuryazarlık ölçeğinin öğretmen adayları üzerinde geliştirilmesi göz önünde bulundurulduğunda, öğretmenlere yönelik bir dijital okuryazarlık ölçeğinin geliştirilmesi önerilebilir.

\section{EXTENDED ABSTRACT}

The Ministry of National Education defined "General Competencies for Teaching Profession" with three complementary competency areas, "professional knowledge", "professional skills", "attitudes and values" for updates to the competencies in the profession of teachers (Ministry of National Education, 2020). In the field of skills competence, "Teaching and Managing the Learning Process" competency "Using information and communication technologies effectively." It is related to the use of technology by teachers in the matter. Also, under the heading of Professional Knowledge, "Field Education Knowledge" and another competency, Attitudes and Values, The use of technology can also be indirectly associated with other competencies under these three competencies.

Rapidly, today's technological tools can be made accessible at the point where various mobile devices become widespread and individual mobile devices become available. The education system was 
also affected by such a digitalization environment and projects and studies of digital tools started to be carried out in education programs. Digital tools attract attention in terms of offering rich and benevolent content by saving the educational environment from the boundaries of time and space. With the announcement of the Covid-19 pandemic in March 2020 and the subsequent measure against the epidemic, 'digital tools' advantages in education, face-to-face training was suspended. Sustainable education and training as well as in education and training as distance education in Turkey. The use of technology in education has become more widespread with the pandemic. This process is possible to convey to us that as digital natives appealing to old students and as digital immigrants, teachers can adapt and use information communication technologies in their lessons. Transformation in education should benefit from digital transformation, and it should be ensured that the planned efficiency reaches the ability to use teachers and digital tools, who are active participants of priority educational environments for advertising. The use of technology, which is associated with the teaching profession's general competence areas, is an important competency area that teachers should have. The concept of digital literacy skill, which is defined as the ability of individuals to use information technologies effectively, to choose the processes of understanding and use of information, to access digital resources and to use these resources correctly, is encountered in the literature. In order for the future to spend quality time in the next generation digital life, primary teachers are expected to have digital literacy. It is considered important for teachers to become digital literate first and then to become digital productive.

In this study, it is aimed to examine the digital literacy skills of classroom teachers depending on various variables. This study was created using the survey model, one of the quantitative research methods. Classroom teachers working in a total of 41 provinces from seven geographical regions of Turkey participated in the study. The study group of the research consists of 186 women and 143 men, in total 329 teachers. The teachers participated in the research voluntarily. As data collection tools, teachers' gender, age, education level, seniority year; "Personal Information Form" containing questions about daily television watching, internet usage, computer tablet and smart phone usage times and "Digital Literacy Scale" developed by Ng (2012) were used. Descriptive statistics, unrelated samples t test and one-way analysis of variance (One WAy ANOVA) for unrelated measurements were used to analyze the data. In addition, Confirmatory Factor Analysis (CFA) was applied to examine the construct 
validity of the Digital Literacy Scale used within the scope of the study, and Cronbach's alpha coefficient was calculated for reliability. SPSS 25 and LISREL 8.8 software were used to analyze the data.

According to the findings obtained from the research, it was concluded that classroom teachers consider themselves highly digitally literate. When looking at the digital literacy levels of classroom teachers regarding the gender variable, it is among the findings that male and female teachers are digitally literate at a similar level. It has been observed that the average score of classroom teachers between the ages of 20-30 is higher than the mean scores of teachers aged 41 and over, and the digital literacy level decreases as the age of teachers increases. The reason for this can be explained by the fact that teachers with a high level of age meet technology and digital tools late compared to young teachers, and they have difficulty in abandoning their habits. It has been found that the digital literacy levels of classroom teachers with a seniority of 21-25 years are lower than those with a seniority of 0-5 years. The reason for this is thought to be that senior teachers of 0-5 years have become acquainted with digital tools and media at an earlier age. In the studies in the literature, it has been found that teachers with seniority over 20 years continue to use classical technologies. In addition, it has been observed that teachers with postgraduate education have higher digital literacy levels compared to other teachers. When we look at teachers' daily internet usage and daily digital tools usage, no significant differentiation was observed.

Based on the results of the research, comprehensive educational projects can be developed to improve teachers' digital literacy levels in order to enable classroom teachers to enrich their lessons with digital tools, to make tool choices, to use digital tools in a technical sense, and to develop content suitable for the levels of students especially for teaching.

\section{KAYNAKÇA}

Ahmet, Ö., \& Yıldız, K. (2019). Okul yöneticilerin ve öğretmenlerin kendilerini teknoloji okuryazarı olarakdeğerlendirmelerine ilişkin görüşlerinin incelenmesi School adminisrators and teachers opinions on their evaluation of self as a technology literacy. Zeitschrift Für die Welt der Türken/Journal of World of Turks, 341-350.

Akkoyunlu, B. (2002). Öğretmenlerin internet kullanımı ve bu konudaki öğretmen görüşleri. Hacettepe Üniversitesi Eğitim Fakültesi Dergisi, 22, 1-8. 
Alexander, P. A., Fox, E., Maggioni, L., Loughlin, S. M., Baggetta, P., Dinsmore, D. L., . . Dumas, D. (2012). Reading Into the Future: Competence for the 21st Century. Educational Psychologist, 47(4), 259280.

Alhazza, T. C., \& Lucking, R. (2017). An examination of preservice teachers' view of multiliteracies: Habits,. Reading Improvement, 54(1), 32-43.

Aslan, A., \& Zhu, C. (2017). Investigating variables predicting Turkish pre-service teachers' integration of ICT into. British Journal of Educational Technology, 48(2), 552-570. doi:doi:10.1111/bjet.12437

Ata, R., \& Yıldırım, K. (2019). Exploring Turkish pre-service teachers' perceptions and views of digital literacy. Education Sciences, 9(1), 40. doi:https://doi.org/10.3390/educsci9010040

Barut, L. (2015). Fen ve teknoloji öğretmenlerinin eğitimde teknoloji kullanımına yönelik tutumları ile bilgisayar öz yeterlik algıları arasındaki ilişki. Kahramanmaraş: Sütçü İmam Üniversitesi.

Boyacı, Z. (2019). Öğretmen adaylarııı yaşam boyu öğrenme eğilimleri ile dijital okuryazarlık düzeyleri arasındaki ilişki. Sakarya: Sakarya Üniversitesi.

Bozkurt, A. (2020). Koronavirüs (Covid-19) pandemi süreci ve pandemi sonrası dünyada eğitime yönelik değerlendirmeler:Yeni normal ve yeni eğitim paradigması. Açıöğretim Uygulamaları ve Araştırmaları Dergisi, 112-142.

Bozkurt, A., Jung, I., Xiao, J., Vladimirschi, V., Schuwer, R., Egorov, G., .. Paskevicius, M. (2020). A global outlook to the interruption of education due to COVID-19 Pandemic: navigating in a time of uncertainty and crisis. Asian Journal of Distance Education, 1-126.

BTK \& Yeşilay. (2014). Internetin bilinçli kullanımı ve teknoloji bağımılı̆̆ı çalıştayı raporu. Ankara: Detamat. https://www.guvenliweb.org.tr/dosya/MUUMu.pdf adresinden alındı

Büyüköztürk, Ş. (2010). Sosyal bilimler için veri analizi el kitabı. Ankara: Pegem Akademi.

Büyüköztürk, Ş., Kıllı̧ Çakmak, E., Akgün, Ö. E., Karadeniz, Ş., \& Demirel, F. (2011). Bilimsel araştırma yöntemleri. Ankara: Pegem Akademi.

Cohen, L., Manion, L., \& Morrison, K. (2017). Research methods in education. Routledge.

Comrey, A. L., \& Lee, H. B. (1992). A First Course in Factor Analysis (2nd ed.). Psychology Press.

Çetin , O. (2016). Pedagojik formasyon ile lisans eğitimi fen bilimleri öğretmen adaylarının sayısa okuryazarlık düzeylerinin incelenmesi. Journal of Education Faculty, 18(2), 658-685.

Çetin, O. (2016). Pedagojik formasyon programı ile lisans eğitimi fen bilimleri öğretmen adaylarının sayısal okuryazarlık düzeylerinin incelenmesi. Journal of Education Faculty, 18(2), 658-685.

Güder, O., \& Demir, M. (2018). Sınıf öğretmenlerinin fen bilimleri dersine yönelik teknolojik pedagojik alan bilgisi özgüven algılarının cinsiyet, yaş ve görev yapılan okul türü açısından incelenmesi. Uşak Üniversitesi Eğitim Araştırmaları Dergisi, 4(2), 51-68.

Güneş, A. M., \& Buluç, B. (2017). Sınıf öğretmenlerinin teknoloji kullanımları ve öz yeterlik inançları arasındaki ilişki. TÜBAV Bilim Dergisi, 10(1), 94-113. 
Hakkari, F., Tüysüz, C., \& Atalar, T. (2016). Öğretmenlerin bilgisayar yeterlikleri ve öğretimde teknoloji kullanımına ilişkin algılarının çeşitli değişkenler bakımından incelenmesi. Bayburt Eğitim Fakültesi Dergisi, 10(2), 460-481.

Hamutoğlu, N. B., Güngören, Ö. C., Kaya Uyanık, G., \& Gür Erdoğan, D. (2017). Dijital okuryazarlık ölçeği: Türkçe'ye uyarlama çalışması. Ege Eğitim Dergisi, 18(1), 408-429.

Hu, L.-T., \& Bentler, P. M. (1995). Evaluating model fit. L.-T. Hu, P. M. Bentler, \& R. H. (Ed.) (Dü.) içinde, Structural equation modeling: Concepts, issues, and applications (s. 76-99). Washington: Sage Publications, Inc.

Jackson, S. L. (2015). Research methods and statistics: A critical thinking approach. Boston: Cengage Learning.

Joreskog, K. G., \& Sörbom, D. (1993). LISREL 8: Structural equation modeling with the SIMPLIS command language. Scientific Software International.

Kabakçı Yurdakul, I., Dönmez, O., Yaman, F., \& Odabaşı, H. F. (2013). Dijital ebeveynlik ve değişen roller. Gaziantep University of Social Sciences, 12(4), 883-896.

Kane, S. (2017). Literacy and Learning in the content areas. New York: Routledge.

Karabacak, Z. I., \& Sezgin, A. A. (2019). Türkiye'de dijital dönüşüm ve dijital okuryazarlık. Türk Idare Dergisi, 1(488), 319-343.

Karakuş Yılmaz, T. (2020). Dijital haklar ve sorumluluk. T. Karakuş Yılmaz içinde, Dijital Okuryazarlık: Araçlar, Metodolojiler, Uygulamalar ve Öneriler (s. 159). Ankara: Nobel.

Kline, R. B. (2005). Methodology in the social sciences.Principles and practice of structural equation modeling (2nd ed.). Guilford Press.

Leech, N. L., Barret, K. C., \& Morgan, G. A. (2005). Spss for intermediate statistics: use and Interpretation. London: Lawrence Erlbaum Associates.

Li, Y., \& Ranieri, M. (2010). Are 'digital natives' really digitally competent? -A study on Chinese teenagers. British Journal of Educational Technology, 41(6), 1029-1042. doi:DOI: 10.1111/j.14678535.2009.01053.x

List, A., Brante, E. W., \& Klee, H. L. (2020). A framework of pre-service teachers' conceptions about digital literacy: Comparing the united states and sweden. Computer \& Education.

Maden, S., Banaz, E., \& Maden, A. (2018). Türkçe öğretmeni adaylarının dijital ortamlardaki yazma alışkanlıkları. Eğitim ve Öğretim Araştırmaları Dergisi, 7(1), 103-112.

Martin, A. (2005). Digeulit a european framework for digital literacy: a progress. Journal of e Liteeracy, 2, 130-136.

Metin Taş, A. (2019). Öğretmen yeterlikleri. A. Metin Taş, B. Aslan, \& F. Hazır Bıkmaz (Dü) içinde, Prof. Dr. Mehmet Ali Kısakürek'e Armağan (s. 75-82). Ankara: Ankara Üniversitesi Basımevi.

Milli Eğitim Bakanlığı. (1973, 6 14). Milli Eğitim Temel Kanunu. https://oygm.meb.gov.tr/meb_iys_dosyalar/2017_11/08144011_KANUN.pdf adresinden alındı 
Milli Eğitim Bakanlığı. (2020). Öğretmen mesleği genel yeterlikleri. Ankara: Öğretmen Yetiştirme ve Geliştirme Genel Müdürlüğü.

Ng, W. (2012). Can we teach digital natives digital literacy? Computers \& Education, 53(3), 1065-1078.

OECD. (2021, 1 29). Teachers matter: attracting, developing and reatining effective teachers. https://www.oecd.org/education/school/34990905.pdf adresinden alındı

Özbay, M., \& Özdemir, O. (2014). Türkçe öğretim programı için bir öneri: Dijital okuryazarlığa yönelik amaç ve kazanımlar. Okuma Yazma Eğitimi Araştırmaları, 31-40.

Özbek, Y. (2020). Sınıf öğretmenlerinin dijital içerik ve teknoloji kullanma becerileri. Denizli: Pamukkale Üniversitesi.

Özçelik, A., \& Yıldız, K. (2019). Okul yöneticilerinin ve öğretmenlerin kendilerini teknoloji okuryazarı olarak değerlendirmelerine ilişkin görüşlerinin incelenmesi. Zeitschrift für die Welt der Türken/Journal of Turks, 11(2), 341-360.

Özerbaş, M. A., \& Güneş, A. M. (2015). Sınıf öğretmenlerinin ilkokuma yazma sürecinde eğitim teknolojilerini kullanmaya yönelik görüşleri. Kastamonu Eğitim Dergisi, 23(4), 1775-1788.

Özerbaş, M. A., \& Kuralbayeva, A. (2018). Türkiye ve kazakistan öğretmen adaylarının dijital okuryazarlık düzeylerinin incelenmesi. Muğla Sıtkı Koçman Üniversitesi Eğitim Fakültesi Dergisi, 16-25.

Pala, Ş. M., \& Başıbüyük, A. (2020). Ortaokul beşinci sınıf öğrencilerinin dijital okuryazarlık düzeylerinin incelenmesi. Cumhuriyet InternationalJournal of Education, 9(3), 897-921.

Prensky, M. (2001). Digital game based learning. New York: McGraw-Hill.

Ribble, M. (2011). Digital citizenship in schools. Washington: International Society for Technology in Education.

Salajan, F. D., Schönwetter, D. J., \& Cleghorn, B. M. (2010). Student and faculty inter-generational digital divide: Fact or fiction? Computers \& Education, 55(3), 1393-1403.

Seferoğlu, S. S. (2001). Öğretmen yeterlilikleri ve mesleki gelişim. Bilim ve Aklın Aydınlı̆ıında Eğitim, 117125.

Soby, M. (2008). Digital Competence From Education Policy to Pedagogy: The Norwegian Context. M. Soby, C. Lankshear, \& M. Knobel (Dü) içinde, Digital Literacies (s. 119-150). New York: Peter Lang Puplishing.

Spante, M., Hashemi, S. S., Lundin, M., \& Algers, A. (2018). Digital competence and digital literacy in higher education research: Systematic review of concept. Cogent Education, 5(1), 1-21. doi: https://doi.org/10.1080/2331186X.2018.1519143

Steiger , J. H. (2007). Understanding the limitations of global fit assessment in structural equation modeling. Personality and Individual Differences, 893-898.

Sulak, S. E. (2019). Dijital okuryazarlık ölçeğinin geliştirilmesi: Geçerlik ve güvenirlik çalışması. International Social Sciences Studies Journal, 5(31), 1329-1342. 
Sur, D. (2012). Meslek liselerinin büro yönetimi ve sekteretlik programlarında görev yapan öğretmenlerin eğitim teknoloilerini kullanma düzeylerini belirlemeye yönelik bir araştırma. Ankara: Gazi Üniveristesi Eğitim Bilimleri Enstitüsü.

Sümer, N. (2000). Yapisal Eşitlik Modelleri: Temel Kavramlar ve Örnek Uygulamalar [Structural Equation Modeling: Basic Concepts and Applications]. Türk Psikoloji Yazilari, 3(6), 49-74.

Şahin, A. E. (2004). Öğretmen yeterliklerinin belirlenmesi. Bilim ve Aklın Aydınlığında Eğitim, 5, 58-62.

T.C. Milli Eğitim Bakanlığı. (2020). Dijital okuryazarlı öğretmen klavuzu. Meb.gov.tr.

T.C. Milli Eğitim Bakanlığı Strateji Geliştirme Başkanlığı. (2020, 12 26). Milli eğitim istatistikleri örgün eğitim.

Tabachnick, B. G., \& Fidell , L. S. (2001). Using Multivariate Statistics (Fourth Edition). Needham Heights: MA: Allyn \& Bacon.

Tatlı, A. (2018). Öğretmenlerin dijital vatandaşlık düzeylerinin bilgi okuryazarlığı ile internet ve bilgisayar kullanım özyeterlikleri bağlamında değerlendirilmesi. Konya: Necmettin Erbakan Üniversitesi.

Tondeur, J., Aesaert, K., Prestridge, S., \& Consuegra, E. (2018). A multilevel analysis of what matters in the training of pre-service teacher's ICT competencies. Computers \& Education, 122, 32-42. doi:https://doi.org/10.1016/j.compedu.2018.03.002

Ulaş, A. H., \& Ozan, C. (2010). Sınıf öğretmenlerinin eğitim teknolojileri açısından yeterlik düzeyi? Journal of Graduate School of Social Sciences, 14(1), 63-84.

Yalçın, S. (2018). 21. yüzyıl becerileri ve bu becerilerin ölçülmesinde kullanılan araçlar. Ankara Üniversitesi Eğitim Bilimleri Fakültesi Dergisi, 51(1), 183-201.

Yazıcıoğlu, A., Yaylak, E., \& Genç, G. (2020). Okulöncesi ve sınıf öğretmen adaylarının dijital okuryazarlık düzeyleri. ODÜ Sosyal Bilimler Araştırmaları Dergisi, 10(2), 274-286.

Yıldırım, Ö., \& Kurşun, E. (2020). İnternet beceriileri ve türleri. Ö. Yıldırım, E. Kurşun, Ş. Sağıroğlu, H. i. Bülbül, A. Kılıç, \& M. Küçükali (Dü) içinde, Dijital Okuryazarlık Araçlar, Metodolojiler, Uygulamalar ve Öneriler (s. 98). Ankara: Nobel.

Yontar, A. (2019). Öğretmen adaylarının dijital okuryazarlık düzeyleri. Ana Dili Eğitimi Dergisi, 7(4), 815824.

Zhou, M. (2014). Gender difference in web search perceptions and behavior: Does it vary by task performance? . Computers \& Education, 78, 174-184. doi:http://dx.doi.org/10.1016/j.compedu.2014.06.005 